\title{
LOS EMIGRADOS FRANCESES Y LA EVOLUCIÓN DEL AFRANCESAMIENTO EN ESPAÑA
}

\section{The French Emigrants and the Evolution of Frenchification in Spain}

\author{
Emilio Luis LARA LÓPEZ \\ IES El Valle. Jaén \\ emijaen@yahoo.es \\ Fecha de recepción: 13/01/2015 \\ Fecha de aceptación: 26/04/2016
}

RESUMEN: Con los Borbones españoles se introducirán progresivamente los moldes culturales galos y nacerá un afrancesamiento cultural al que se adherirá gran parte de las élites ilustradas. Los terremotos continuados de la Revolución francesa y de la Guerra de la Convención alterarán la vida española en varias facetas, sobre todo debido a los emigrados franceses. Estos exiliados -sobre todo los clérigosinculcarán en las capas populares un sentimiento contrarrevolucionario que el clero español convertirá en una animadversión francesa de tintes religiosos y xenófobos. Estos prejuicios latentes rebrotarán en 1808, lo que, en parte, ayudará a explicar la fulminante reacción antinapoleónica. Los afrancesados apostarán por la nueva monarquía bonapartista por razones políticas con la finalidad de regenerar el país. Los franceses residentes desde antaño en España sufrirán al principio de la guerra la ira de sus vecinos españoles o serán objeto de sospecha.

Palabras clave: Ilustración; Guerra de la Convención; emigrados; Bonaparte; Guerra de la Independencia; afrancesados.

ABSTRACT: With the Spanish Bourbons, there was a gradual introduction of Gallic cultural forms that gave rise to Frenchification, or cultural afrancesamiento, which was supported by most of the enlightened elite. The continual upheavals of the French Revolution and of the War of the Pyrenees were to change Spanish 
life in several of its facets, due in particular to the French emigrants. These exiles -above all, the clergymen- instilled in the popular classes a counterrevolutionary feeling that the Spanish clergy was to turn into a resentment of the French with religious and xenophobic overtones. Such latent prejudices were to reappear in 1808, in part helping to explain the forceful anti-Napoleonic reaction. The afrancesados supported the new Napoleonic Monarchy for political reasons with the purpose of regenerating the country. French residents in Spain from long before had to endure the anger of their Spanish neighbours at the beginning of the war as well as live under the cloak of suspicion.

Key words: Enligthtenment; War of the Convention; emigrants; Bonaparte; Peninsular War.

Cada vez disponemos de mejores estudios sobre el fenómeno del afrancesamiento durante la Guerra de la Independencia, acerca de los españoles que, por razones esencialmente políticas ${ }^{1}$, se declararon partidarios de José I y contribuyeron con decisión a edificar una efímera monarquía regeneracionista, a construir un Estado de papel mojado. Igualmente, existen trabajos de calidad académica que analizan la enorme influencia que en España tuvieron la Ilustración y las formas culturales de origen francés. Sin embargo, no abundan los estudios que centren su atención en cómo el afrancesamiento cultural dieciochesco de las élites urbanas fue contrarrestado en muy poco tiempo por franceses exiliados: los emigrados -laicos y eclesiásticos- que abandonaron su turbulento país entre 1789 y 1795, y cómo este odio se extendió como una mancha de aceite por el país, tensionando las relaciones entre franceses residentes y españoles por cuestiones ideológicas y socioeconómicas. Los clérigos emigrados, por medio de sus relatos experienciales, inculcarán en gran parte del clero hispano y en el pueblo llano una profunda animadversión hacia los revolucionarios, y esta inquina de tintes xenófobos y religiosos reverdecerá durante 1808. Así, en el tracto final de la monarquía de Carlos IV, se demostrará que el afrancesamiento cultural no fue semillero de afrancesados, puesto que éstos abrazaron la causa de José I por razones ideológicas.

Este artículo pretende dar una visión general de la evolución del concepto de afrancesamiento desde el s. XVIII hasta la invasión napoleónica, de los choques sociales entre españoles y franceses que vivían en nuestro país a partir de 1789 y cómo estos conflictos no estuvieron centrados en la corte, sino que se vivieron en todos los rincones de la nación.

1. Fernández Sarasola, Ignacio. "Los afrancesados. Revisión de un concepto". En Ramos SANTANA, Alberto y ROMERO FERRER, Alberto (coords.). Liberty, liberté, libertad: el mundo hispánico en la era de las revoluciones. 1. Revolución francesa vs. Revolución afrancesada. Cádiz: Universidad de Cádiz, 2010, pp. 23-52. Moliner PradA, Antonio. "La España josefina: los afrancesados». Revista de Historia Militar, 2008, núm. extraordinario, pp. 27-64. 


\section{El AFRANCESAMIENTO CULTURAL DE RAIGAMBRE DiECIOCHESCA}

Durante la segunda mitad del s. XVIII, la influencia política, social y cultural francesa en toda Europa tendrá su refrendo en las élites hispanas urbanas, que asumirán que para favorecer en gran medida el progreso social y político será imprescindible aprender francés. Este proceso de drenaje cultural francés en España será además impulsado por la dinastía borbónica iniciada con Felipe V². El Siglo de las Luces será genuinamente francés, lo que fomentará la galomanía entre la nobleza y la burguesía, un afrancesamiento de estirpe ideológica que se explicitará en la literatura ${ }^{3}$, el arte, el teatro, la vestimenta ${ }^{4}$, el mobiliario ${ }^{5}$, la gastronomía ${ }^{6}$, el urbanismo ${ }^{7}$, el arte de la guerra ${ }^{8}$, etc. Ahora bien, esta asunción de lo francés por parte de las élites abonará el resentimiento social -con ingredientes xenófobos- del pueblo llano, defensor a ultranza de unos modos de vida y costumbres tradicionales frente a los aristócratas y burgueses que usaban pelucas empolvadas, lujosas vestimentas, exhibían gustos refinados y empleaban un lenguaje trufado de galicismos, signos externos de una decadente frivolidad que se identificará con las peligrosas ideas subversivas francesas, porque "ipuede haber algo más excéntrico

2. Valga como ejemplo que Feijoo, uno de los máximos representantes de la Ilustración en España, fue un defensor a ultranza del pensamiento ilustrado francés, tal y como puede testimoniarse en su obra. Ver Elizalde, Ignacio. "Feijoo y la influencia de los libertinos eruditos franceses». En Actas del VII Congreso de la Asociación Internacional de Hispanistas. Roma: Bulzoni Editore, 1982, pp. 407-418.

3. LAFARGa MADUELl, Francisco. "Sobre recepción de la literatura francesa en España». Thélème: Revista Complutense de Estudios Franceses, 1995, 8, pp. 31-47.

4. MOLINA MARTín, Álvaro. Vestir la identidad, construir la apariencia. La cuestión del traje en la España del siglo XVIII. Madrid: Ayuntamiento de Madrid, 2004.

5. VV. AA. Carlos IV. Mecenas y coleccionista. Madrid: Patrimonio Nacional, Ministerio de Cultura, Sociedad Estatal de Conmemoraciones Culturales, 2009, p. 243.

6. La cocina francesa se implantará en España a lo largo del s. XVIII, pero no sólo por irradiación de los hábitos de los reyes de la nueva dinastía borbónica, sino también a través de los recetarios de los conventos, hasta llegar a los figones, mesones y viviendas particulares. Ver Ruiz TorRes, Manuel J. «La larga transición: cocina y alimentación en el Cádiz sitiado». En RAmos SANTANA, Alberto (coord.). Ocio y vida doméstica en el Cádiz de las Cortes. Cádiz: Diputación de Cádiz, 2012, pp. 57-72.

7. El "prurito civilizador" miraba a Francia, cuyas ciudades fueron el modelo constructivo, sobre todo para dotar a las ciudades españolas de unos paseos señoriales anchos y largos que las embellecieran, además de aplicar en edificios, plazas y calles criterios de racionalidad. La propuesta francesa de trasladar los cementerios extramuros en 1774 por motivos higienistas será recogida por los ilustrados españoles, que en el reinado de Carlos IV encontrarán múltiples obstáculos eclesiales para construir camposantos allende el perímetro urbano, siendo una de las medidas abordadas durante la monarquía josefina. Véase Calatrava, Juan Antonio. «El debate sobre la ubicación de los cementerios en la España de las Luces: la contribución de Benito Bails». Espacio, Tiempo y Forma, Serie VII, Historia del Arte, 1991, 4, pp. 249-366.

8. GARCía HurTAdo, Manuel-Reyes. "La tinta y la sangre: las traducciones de tratados militares franceses en la España del siglo XVIII (1700-1808)». Obradoiro de Historia Moderna, 1997, 6, pp. 47-78. 
y provocativo que empolvarse la cabeza con la harina que el pueblo necesita para su propia subsistencia?"?.

Los escasos viajeros españoles allende nuestras fronteras consignarán por escrito sus impresiones sobre Francia, sobremanera de Paris, ciudad que les deslumbrará por su modernidad ${ }^{10}$. Por el contrario, los viajeros europeos no incluirán España como obligada etapa del Grand Tour y no sólo por la insegura y atrasada red viaria, sino por la mala imagen del país y de sus habitantes forjada en la literatura de viajes, y que tanto contribuyó a fijar el imaginario colectivo europeo sobre los españoles ${ }^{11}$. Sin embargo, promediado el s. XVIII, recorrerán España linternistas -muchos de ellos extranjeros- con una panoplia de artefactos ópticos que permitían visionar placas pintadas que mostraban panorámicas de ciudades europeas, entre las que descollaba Paris. Los dueños de estos mundonuevos o titilimundis montaban sus espectáculos visuales en las plazas, en barracas e incluso en teatros y en salones de la aristocracia y de la alta burguesía, lo que constituyó el primer uso de las imágenes como medio de transmisión cultural y forma de «entretener y educar", tal y como defendían los pensadores ilustrados dieciochistas ${ }^{12}$. El formidable éxito popular del visionado de la realidad por medio de artilugios ópticos como la linterna mágica, le concederá una gran credibilidad social a las imágenes como forma vicaria de conocimiento del mundo ${ }^{13}$. Francia también entrará por los ojos.

En 1770 el término afrancesado estará consignado en el Diccionario de la Real Academia para referirse a la persona que «imitaba con afectación las costumbres francesas». Incluso tras la Paz de Basilea (1795), durante la privanza de Godoy, el afrancesamiento cultural tendrá gran predicamento entre los estratos sociales

9. FuENTES, Juan Francisco. "Moda y lenguaje en la crisis social del Antiguo Régimen». En AYMES, Jean-René (ed.). L'image de la France en Espagne pendant la seconde moitié du XVIIIe siècle. Paris: Instituto de Cultura Juan Gil-Albert-Presses de la Sorbonne Nouvelle, 1996, p. 99.

10. Sirvan como ejemplo Luzán y sus Memorias de Paris (1751) y el duque de Almodóvar y su Década Epistolar (1781). En este sentido, Aguilar PIÑAl, Francisco. "Conocimiento de Alemania en la España ilustrada». Chronica Nova, 1991, 19, pp. 19-30, en concreto la p. 21.

11. Vega GonzÁLEZ, Jesusa. "Viajar a España en la primera mitad del s. XIX: una aventura lejos de la civilización". Revista de Dialectología y Tradiciones Populares, 2004, 59, cuaderno 2, pp. 93-125. Asimismo, para el ámbito femenino, TAMARIT VALLÉs, Inmaculada. Representaciones de la mujer española en el imaginario francés del siglo XVIII. Tesis doctoral. Valencia: Universidad de Valencia, 2003.

12. Para completar información sobre estas experiencias icónicas que tan exitosas fueron entre todos los estamentos sociales, ver BrunetTA, Jean Piero. «El dorado de los pobres: los viajes del icononauta». En Riego AmézAga, Bernardo (coord.). Memorias de la mirada. Las imágenes como fenómeno cultural en la España contemporánea. Santander: Fundación Marcelino Botín, 2001, pp. 27-44. VEGA GonzÁlez, Jesusa. Ciencia, Arte e Ilusión en la España Ilustrada. Madrid: CSIC-Ediciones Polifemo, 2010. VEGa GonZÁLEZ, Jesusa. "Monumentalizar la ciudad y registrarla, una contribución moderna al conocimiento". Revista de Dialectología y Tradiciones Populares, 2011, 66, cuaderno 1, pp. 229-240.

13. Frutos Esteban, Francisco Javier. "La linterna mágica: de la invención a la decadencia (siglos XVII-XX)». Historia Contemporánea, 2008, 36, cuaderno 1, pp. 9-32. 
más cultivados del país ${ }^{14}$, y no sólo en Madrid y la corte, pues este fenómeno se extenderá por las capitales y principales ciudades ${ }^{15}$. Pero no sólo la burguesía, sino que la aristocracia dieciochesca española, tan conservadora y tradicionalista en sus usos y costumbres, también caerá bajo el influjo cultural francófilo, al menos hasta el estallido revolucionario de $1789^{16}$. El interés por la lengua francesa y por las corrientes de pensamiento nacidas en el país transpirenaico no harán sino ganar prestigio a comienzos del s. XIX ${ }^{17}$. Aprender ese idioma era algo de buen tono, lo que explica la profusión de manuales y gramáticas para el estudio de la lengua y también el enorme interés por leer determinadas obras sin necesidad de ser traducidas ${ }^{18}$. No era de extrañar que, al principio del reinado de Carlos IV, la nobleza cortesana adoptase «un tono exclusivamente francés», y que en sus casas se hablase ese idioma de manera habitual ${ }^{19}$.

El interés por los filósofos franceses será una característica común entre las élites provinciales mucho antes de la explosión revolucionaria de 1789. Muchos de sus escritos sortearon el control inquisitorial por distintos cauces, y así, en los valles pirenaicos navarros, se adquirían libros editados en Francia que redundaron en el espíritu ilustrado y modernizador del antiguo reino ${ }^{20}$. Además, en la segunda mitad del s. XVIII se desarrolla un nuevo fenómeno en Europa: la notoriedad de los intelectuales y artistas -muchos de ellos franceses- trasciende las fronteras nacionales, lo que llevará a las élites ilustradas a desarrollar una creciente sensibilidad por conocer las vidas de esas personas cimeras ${ }^{21}$.

14. Fernández Sebastián, Javier y Fuentes, Juan Francisco (dirs.). Diccionario político y social del siglo XIX español. Madrid: Alianza Editorial, 2002, p. 74.

15. Libros y folletos franceses -incluso de propaganda republicana- serán introducidos vía portuaria en España durante la Guerra de la Convención, teniendo acceso a dichas publicaciones los sectores ilustrados de diversas ciudades. A este respecto, véase EsPejo CALA, Carmen. «El diálogo con las ideas republicanas en la prensa popular sevillana de 1793". Cuadernos de Ilustración y Romanticismo, 2010, 16, pp. 1-11.

16. Diz, Alejandro. "Nueva axiología de la España del siglo XVIII en el contexto europeo». Cuadernos Dieciochistas, 2000, 1, pp. 349-380.

17. Calvo Maturana, Antonio. Cuando manden los que obedecen. La clase politica e intelectual de la España preliberal (1780-1808). Madrid: Marcial Pons, 2013.

18. García Bascuñana, Juan F. "¿Con qué libros se aprendía francés en España en 1808?». Anales de Filología Francesa, 2008, 16, pp. 73-85. El Real Colegio Seminario de San Telmo, fundado en Sevilla en 1681, era una Escuela Náutica donde estudiaban niños huérfanos o de escasos recursos que, a partir de las ordenanzas de Carlos III de 1786, incorporó profesores de lenguas modernas para impartir francés. Pons Rodríguez, Lola y SÁEz Rivera, Daniel M. "La enseñanza escolar de la Lengua española en Andalucía en los umbrales del XIX: introducción al Diálogo Ortográfico de A. Balbina Lozano». Cuadernos Dieciochistas, 2012, 13, pp. 111-146.

19. Girón, Pedro Agustín, Marqués de las Amarillas. Recuerdos (1778-1837). Pamplona: Eunsa, 1978 , p. 89.

20. FERnández SEBASTIÁn, Javier. "Opinión pública, prensa e ideas políticas en los orígenes de la Navarra contemporánea, 1762-1823". Príncipe de Viana, 1989, 188, pp. 579-640.

21. Lilti, Antoine. Figures publiques. L'invention de la celebrité (1750-1850). Paris: Fayard, 2014. 
Una eficaz manera de canalización del afrancesamiento cultural lo constituían los cafés (a mitad de camino entre los salones aristocráticos y las tabernas) y las tertulias mantenidas en ellos ${ }^{22}$, donde los burgueses se ponían al día de las novedades intelectuales europeas a través de conversaciones, periódicos leídos y debatidos y opiniones de extranjeros afincados en ciudades españolas por motivos profesionales o, también, de compatriotas que habían viajado a Francia y traían noticias de primera mano. Frente a los canales ilustrados institucionalizados como las universidades y las Sociedades Económicas de Amigos del País, los cafés serán un vehículo más libérrimo para la difusión de las ideas procedentes de Francia, pues a ellos acuden todos los estratos de la burguesía (para tomar bebidas que no fuesen vino, circunscrito a las tabernas, frecuentadas por la plebe), donde formaban corrillos y se convertían en tertulianos donde el intercambio de opiniones no estaba sometido a ninguna norma protocolaria, como sucedía en los salones de la aristocracia.

Sin embargo, esta impregnación ideológica y cultural de lo francés no será el germen del subsiguiente afrancesamiento político de 1808, es decir, de quienes apoyaron la monarquía bonapartista en la persona de José I. Y ello porque en el bando patriota, sobre todo en la facción liberal, hubo numerosos hombres -y mujeres- que se habían nutrido años atrás de la pujante y prestigiosa cultura francesa junto -no hay que olvidarlo- con la inglesa ${ }^{23}$.

El contrapunto del afrancesamiento cultural en la nobleza fue el relativo éxito del majismo: la adopción por un sector de la aristocracia en el reinado de Carlos IV de unos usos sociales (lingüísticos, vestimenta, exaltación de festejos populares) tenidos como la quintaesencia de los valores tradicionales hispánicos. Esta plebeyización aristocrática supondrá un intrínseco rechazo de lo foráneo, que se traducirá por un visceral repudio del afrancesamiento cultural, lo que en última instancia suponía una actitud refractaria a todos los valores que los ilustrados trataban de inculcar a los españoles: laboriosidad, honestidad, pureza de costumbres y patriotismo crítico ${ }^{24}$. El majismo verá el afrancesamiento como algo nocivo, inoculador de un afeminamiento en el habla, la moda y las costumbres, y se creará una palabra despectiva para referirse al afrancesado en modas y costumbres: petimetre. Las capas populares se identificaron con el fenómeno del majismo, del casticismo aristocrático. Y Antonio de Capmany, escandalizado durante la etapa

22. FERNÁNDEZ SEBASTIÁN, Javier. "Los primeros cafés en España (1758-1808): nueva sociabilidad urbana y lugares públicos de afrancesamiento». En AYMES, Jean-René (ed.). L'image de la France..., op. cit., pp. 65-82.

23. Podemos citar políticos de la importancia de Quintana, Argüelles, Flórez Estrada o Martínez de la Rosa. A este respecto, Moreno Alonso, M. La forja del liberalismo en España. Los amigos españoles de Lord Holland 1793-1840. Madrid: Congreso de los Diputados, 1997.

24. Morales Moya, Antonio. "España y Europa en tiempos de Carlos IV. Sociedad y Cultura». En MORAles Moya, Antonio (coord.). 1802. España entre dos siglos. Sociedad y Cultura. Madrid: Sociedad Estatal de Conmemoraciones Culturales, 2003, pp. 42-43. 
gubernativa de Godoy con la influencia de las ideas francesas, tronó contra ellas en sendos alegatos (Teatro bistórico-crítico de la elocuencia y Centinela contra franceses) a favor de las viejas tradiciones populares como humus del carácter nacional, pues sólo así la esencia española se libraría de las afeminadas élites corrompidas por la modernidad y el cosmopolitismo.

No es de extrañar que los misioneros, predicadores y moralistas enalteciesen las costumbres autóctonas y vilipendiasen las francesas, por considerar que eran el portillo por donde se colaban las malas costumbres y la vida disoluta. Así, en sus sermones y escritos tronarán contra los pronunciados escotes, el lujo, los tacones, los cosméticos, los trajes poco honestos, las modas indecentes y provocativas de las que hacían gala las madamas, las mujeres que vestían a la francesa ${ }^{25}$.

Otra variante del frontal rechazo al afrancesamiento cultural provendrá de los sermones escritos por el sector ultraconservador del clero para movilizar a los españoles en la Guerra de la Convención. En los sermonarios, se denostará la relajación de costumbres, las modas, los bailes, el teatro, el lujo, los saraos y todo lo que entraba dentro del «espíritu de libertinaje», es decir, lo proveniente de Francia, el enciclopedismo ${ }^{26}$. Tengamos en cuenta que la facción ultramontana del clero tenía ya en su punto de mira las ideas ilustradas de sesgo enciclopedista durante el reinado de Carlos III, como se evidenció tras la reforma universitaria diseñada por Pablo de Olavide, lo que le costó su caída en desgracia política, su enjuiciamiento inquisitorial y su fuga a Paris, meca de todo ilustrado ${ }^{27}$, segunda patria para quienes eran perseguidos en la de nacimiento por sus ideas avanzadas.

Pero habrá un elemento de enorme influencia en las mentalidades de las capas populares que también ayudará a explicar la explosiva reacción antifrancesa en 1808: la religiosidad popular. Esta estructurante forma de vivenciar la religión -desde una perspectiva antropológica y cultural- estará tan anclada en España (sobre todo en la zona meridional) ${ }^{28}$, que habría que valorar cierta capacidad causal a la hora de explicar la rapidez con la que, en 1808, prendió el sentimiento antifrancés en las masas populares. A comienzos del s. XIX, las formas religiosas contrarreformistas seguían plenamente vigentes en España a través de las cofradías laicales o de realengo. Eran miles las hermandades que en Cuaresma y Semana Santa, fiestas patronales o festividades del calendario litúrgico organizaban fiestas religiosas y procesiones en todos los pueblos y ciudades, lo que mantenía

25. García Fernández, Máximo. "Entre cotidianidades: vestidas para trabajar, de visita, para rezar o de paseo festivo". Cuadernos de Historia Moderna, Anejos, 2009, 8, pp. 119-150.

26. Morales Moya, Antonio. "Los conflictos ideológicos en el siglo XVIII español». Revista de Estudios Políticos, 1993, 80, p. 17.

27. Los detalles de los dos años de prisión incomunicada de Olavide, del autillo celebrado por el Santo Oficio y de su posterior huida a Francia pueden verse en GómEZ URDáñez, José Luis y TÉLlEZ AlarCia, Diego. "Pablo de Olavide y Jáuregui, un católico ilustrado». BROCAR, 2004, 28, pp. 7-30.

28. ARIAS DE SAAVEDRA, Inmaculada y LÓPEZ-GuAdalupe MuÑoz, Miguel Luis. "Cofradías y ciudad en la España del siglo XVIII». Studia Historica. Historia Moderna, 1998, 19, pp. 197-228. 
incólume una piedad barroca basada en los ritos colectivos externos y, también, posibilitaba anudar unas estrechas relaciones personales a través de populosas comidas de hermandad ${ }^{29}$. El clero regular tenía gran presencia en la dirección espiritual de las cofradías, en la predicación de sus cultos, en las rogativas públicas y procesiones, por lo que los sermones de los frailes dirigidos a los cofrades estaban imbuidos de ideas contrarrevolucionarias a raíz de la Revolución francesa. Además, la desamortización promovida por Carlos III contra los bienes raíces de las cofradías de realengo y la tímida desamortización eclesiástica efectuada posteriormente por Godoy vacunarán al clero contra la política regalista ilustrada, y no digamos contra las ideas reformistas que pretenderá ejecutar la administración bonapartista personificada en José I o el constitucionalismo gaditano. Estas desamortizaciones privarán a multitud de cofradías de los ingresos obtenidos por la vía de los arrendamientos rústicos, lo que acarreará la extinción de muchas y producirá heridas de muerte a gran número, debiendo cerrar bastantes hospitales y hospitalicos de su propiedad, dejando sin asistencia médica y social a millares de pobres, prefigurando los efectos de la desamortización de Mendizábal en el ámbito de la red de beneficencia.

Por todo lo anteriormente dicho, las masas populares, en 1808, considerarán una afrenta imperdonable las actitudes de las tropas napoleónicas contra el patrimonio religioso: quema de iglesias y conventos, expolio artístico, darle a los edificios eclesiásticos variopintos usos civiles, pero, sobre todo, la destrucción de las imágenes de sus cofradías en hogueras, el fusilamiento de imágenes de Dolorosas y Cristos y la parodia de procesiones pasionistas revestidos los soldados con ropajes litúrgicos y ultrajando cálices y copones. Consideramos, por consiguiente, que la firmemente extendida religiosidad popular asentó a lo largo del s. XVIII y principios del XIX en el pueblo llano unas formas culturales ${ }^{30}$ y un ideario tradicional enfrentados a la Ilustración de cuño galo, lo que ayuda a comprender el furor antifrancés encarrilado por el bajo clero a partir del Dos de mayo ${ }^{31}$.

29. Campomanes acusará a las cofradías de dedicar buena parte de sus recursos económicos a banquetes. El Consejo de Castilla censará en casi 30.000 el número de cofradías peninsulares y estimará que sus rentas eran cuatro veces superiores al presupuesto anual de la Corona. En la exposición de motivos de la disposición real de 9 de mayo de 1778 que suprima muchas de estas asociaciones religiosas, se citarán expresamente "las comilonas y gastos superfluos que hacen en estas cofradías, especialmente cuando llegan a ser oficiales de ellas, en que suele salir la vanidad más que la devoción”.

30. Sería interesante iniciar una investigación en este campo dentro de los parámetros de la novedosa tendencia historiográfica Historia cultural de los sentimientos, según desarrolla BuRKe, P. «Is There a Cultural History of the Emotions?». En Gouk, Penelope y Hilis, Helen (eds.). Representing Emotions: New Connections in the Histories of Art, Music and Medicine. Aldershot: Ashgate, 2005, pp. 35-48.

31. Los afrancesados, conocedores de la frenética actividad política antifrancesa de los frailes exclaustrados, denunciarán detalladamente a las autoridades josefinas a los religiosos regulares adictos al bando patriota, como fue el caso del sureste peninsular. Véase SiLva RAMírEz, Enrique. "Datos para un estudio de la Guerra de la Independencia en Almería». Boletín del Instituto de Estudios Almerienses, 1987, 7, pp. 183-194. 
Volviendo al ámbito de las élites, la fascinación ideológica por Francia rebasará las esferas estrictamente culturales y entrará de lleno en el ámbito político al menos entre 1804 y 1808, y ello a través de la prensa española: la Gazeta de Madrid, órgano periodístico oficial de la monarquía de Carlos IV, contribuirá (de una manera involuntaria en el mejor de los casos) al descrédito de la Corona borbónica y de sus gobernantes al contraponerlos al régimen napoleónico.

La Gazeta de Madrid salía dos días a la semana (martes y viernes) y sus noticias versaban sobre las cortes europeas y una variopinta información nacional. Su respetable tirada era de 10.0000 ejemplares, superando con creces a los demás periódicos españoles ${ }^{32}$. Dicho periódico ensalzará a partir de 1804 la Francia imperial fabricando los gacetistas una imagen casi idílica de Francia debida a una suma de factores: el genio militar de Napoleón, su política regeneracionista (capaz de limar los excesos revolucionarios y de restaurar el orden), el ideario de promoción personal de los más capaces, la abolición de los residuos feudales, la defensa de las nociones de libertad e igualdad y el entusiasmo popular que suscitaban los viajes del emperador. Y todo esto en contraposición a una monarquía hispánica esclerotizada, debilitada por factores internos ${ }^{33}$. Como se decía entonces, había que asumir y legitimar "el nuevo estado de cosas" para evitar caer en la anarquía-identificada entonces con el jacobinismo-, entendida como levantamiento popular y ataques a personas e instituciones.

Otro periódico, la Gazeta de Barcelona, repetirá en 1805 los elogios al sistema napoleónico, afirmando que han terminado los delitos revolucionarios del pasado, que el pueblo francés rinde culto a su emperador por su capacidad para procurar su felicidad y que incluso el Papa celebra la defensa de la Iglesia realizada por Bonaparte ${ }^{34}$.

Ahora bien, los logros ilustrados fueron muy diferentes en ambos países si tomamos como referencia el inicio del reinado de Carlos IV. Mientras en Francia casi el 75\% de la población estaba alfabetizada, en España la proporción era del 15\%. El pueblo llano continuó apegado férreamente a las nociones de defensa del rey, del altar y de sus modos de vida inveterados.

Como hemos visto, el afrancesamiento cultural enraizó en la corte, aunque también cosechó frutos en todas las ciudades, si bien exclusivamente en los sectores más ilustrados. Sin embargo, no actuó como fermento en el afrancesamiento (político) de 1808.

32. Dufour, Gérard. "La Gazeta afrancesada de Madrid (1808-1813)». Cuadernos de Ilustración y Romanticismo, 2010, 16, pp. 1-41.

33. LARRIBA, Elisabel. "La contribución de la Gaceta de Madrid al desprestigio de Carlos IV y del Antiguo Régimen por la exaltación de Napoleón (1804-1808)». Cuadernos de Historia Moderna. Anejos, 2008, VII, pp. 239-276.

34. AYMES, Jean René. "La imagen de Francia y de los franceses en España en 1808». En La Guerra de la Independencia (1808-1814). Perspectivas desde Europa. Actas de las terceras Jornadas sobre la batalla de Bailén y la España Contemporánea. Jaén: Universidad de Jaén, 2002, p. 99. 


\section{ESPAÑA COMO TIERRA DE OPORTUNIDADES}

En el s. XVII existía un nada despreciable flujo migratorio francés hacia España motivado por las oportunidades económicas que se les brindaban tanto en las ciudades como en el campo debido, en gran medida, a la percepción francesa de la natural indolencia y pereza hispanas ${ }^{35}$. Los franceses trabajaron en el campo (jornaleros) y en la ciudad (artesanía y servicio doméstico), y se centraron en oficios como: carboneo, venta ambulante de vinagre y aceite -jarreros-, hospederos, aguadores, chocolateros..., oficios comúnmente despreciados por los españoles. Las ganancias las invertían comprando en su país natal perfumes y diversas mercaderías que revendían en España, obteniendo beneficios que les permitían prosperar. Los artesanos y comerciantes españoles empezaron a quejarse de la competencia desleal de los franceses y los arbitristas recogieron ese descontento ${ }^{36}$, lo que contribuyó a construir una mala imagen social de esos trabajadores foráneos que perdurará en el s. XVIII ${ }^{37}$, centuria en la que las críticas se dirigirán hacia las pujantes compañías comerciales francesas, acusadas de colocar en España manufacturas de su país y de exportar materias primas españolas (lana sobre todo).

La red de intereses franceses abarcaba desde los buhoneros que vendían sus productos de poca importancia por toda la geografía nacional hasta los banqueros instalados en Madrid que manejaban buena parte de los beneficios económicos del comercio colonial americano, y que hasta 1808 alentaron el flujo de metales preciosos fuera de España ${ }^{38}$.

En el XVIII, además de existir una influyente burguesía mercantil y financiera gala, los franceses se dedicarán a múltiples oficios: libreros, joyeros, pintores, escultores, maestros de esgrima o danza, músicos, sederos, sombrereros, zapateros, tejedores..., pero también desempeñarán trabajos de poca cualificación: caldereros, posaderos o jornaleros.

Durante los reinados de Carlos III y Carlos IV los burgueses franceses dinamizan el comercio y las finanzas de buena parte de las ciudades, llegando a controlar los resortes de determinados sectores mercantiles por su carácter emprendedor

35. SAlas AusÉns, José Antonio. En busca de El Dorado. Inmigración francesa en la España de la Edad Moderna. Bilbao: Universidad del País Vasco, 2009.

36. Denostarán la calidad de los extranjeros venidos a España en términos como: "Toda la inmundicia de Europa, sin que haya quedado en Francia, Alemania, Italia y Flandes, y aun en las islas rebeldes, cojo, manco, tullido, ni ciego que no se haya venido...». FERnández NAVARRETE, P. Conservación de Monarquías. Madrid, 1625, discurso IX. Puede consultarse también en GoRDON, Michael D. Moralidad y Política en la España del siglo XVII. Estudio Preliminar a Fernández Navarrete. Madrid: Instituto de Estudios Fiscales, 1982.

37. SAlas AuséNS, José Antonio. "Buscando vivir en la ciudad: trayectorias de inmigrantes franceses en los siglos XVII y XVIII. Revista de Demografía Histórica, 2003, XXI, 1, pp. 145-146.

38. Fontana, Josep. La quiebra de la monarquía absoluta. 1814-1820. La crisis del Antiguo Régimen en España. Barcelona: Crítica, 2002, p. 26. 
y su facilidad para establecer redes de $\operatorname{contactos}^{39}$. Estos poderosos comerciantes se reunirán en asamblea en las ciudades donde tenían una nutrida representación (Cádiz, Sevilla, La Coruña, Vigo, Santander y Valencia), extenderán sus redes por todos los puertos de mar y, para canalizar los intereses de tan poderoso grupo de presión, estarán representados en la corte por un agente real francés que velará por el escrupuloso cumplimiento de los tratados comerciales entre ambas potencias. Así por, ejemplo, en el Madrid de 1761 había censados 51 mercaderes franceses, lo que constituía el 57,3\% del total. La mayoría eran calificados como mercaderes de grueso (mayoristas) y sólo unos pocos como comerciantes de giro o de cambio, o sea, personas dedicadas a actividades bancarias de cambio, giro y crédito. Algunos de ellos habían sido admitidos en el exclusivo gremio de joyeros, dedicado también a la venta de perfumes, juguetes, bolsos y todo tipo de objetos de lujo. Otros franceses no censados (abundaban los buhoneros) adquirían sus mercancías a los mayoristas y se dedicaban a la venta ambulante en Madrid, sus alrededores o en otras poblaciones castellanas ${ }^{40}$.

En Cádiz, la populosa e influyente colonia mercantil francesa tuvo un promedio de 50 a 70 compañías a lo largo del s. XVIII, predominando aquellas que tenían entre dos y siete miembros, siendo la mayoría de carácter familiar ${ }^{41}$, y en 1771 existían en la ciudad 154 casas comerciales francesas: grandes casas de comercio y banqueros (72), detallistas (32) y otros pequeños mercaderes (50) ${ }^{42}$. En 1791, el consulado francés de Cádiz contabilizó un total de 8.885 extranjeros residentes en la ciudad, de los que 2.500 eran franceses $^{43}$. La liberalización del comercio americano y el duopolio que mantuvo la capital gaditana con la sevillana durante años sentaron las bases para que los mercaderes y financieros franceses amasasen grandes fortunas en una ciudad que, a finales del s. XVIII, se había convertido en la más cosmopolita y abierta de miras de España.

En Málaga existía a la altura de 1765 una nutrida colonia francesa dedicada casi en exclusiva a la mercaduría de ropas ${ }^{44}$. En Jaén, la burguesía mercantil francesa

39. Cruz Valenciano, Jesús. Gentlemen, bourgeois and revolutionaires: Political change and cultural persistence among the Spanish dominant groups, 1750-1850. Cambridge: Cambridge University Press, 1996. ZYLBERBERG, Michel. Une si douce domination: les milieux d'affaires français et l'Espagne vers 1780-1808. Paris: IGPDE, 1993.

40. PÉREZ SARRIÓN, Guillermo. "Intereses financieros y nacionalismo. La pugna entre mercaderes banqueros españoles y franceses en Madrid, 1766-1796". Cuadernos de Historia Moderna. Anejo VII, 2008, pp. 31-72.

41. Villar García, María Begoña. "La burguesía de origen extranjero en la España del siglo XVIII». Baetica. Estudios de Arte, Geografía e Historia, 1996, 18, p. 442.

42. Recio Morales, Óscar. "Las reformas carolinas y los comerciantes extranjeros en España: actitudes y respuestas de las "naciones" a la ofensiva regalista, 1759-1793". Hispania, 2012, vol. LXXII, núm. 240, pp. 67-94.

43. Recio Morales, Óscar. "Las reformas carolinas...", op. cit., p. 91.

44. Destacó como mercader Juan Bautista Maury; en 1765, de entre 41 franceses dedicados al ramo del comercio textil, 18 declararon ejercer como mercaderes y 23 como cajeros de aquéllos, es 
superaba a la española a finales del s. XVIII, creando una sociedad mercantil, "Don Juan Paillé y Compañía”, que tras disolverse será sustituida por otra dirigida por Juan Camps ${ }^{45}$; pero también se instalarán en la capital jiennense franceses dedicados al comercio de aceite de oliva y a la industria del pan (a finales del s. XVIII serán propietarios de la mitad de los hornos ${ }^{46}$ y obradores de confitería).

\section{LOS EMIGRAdOS FRANCESES DURANTE LA GUERRA DE CONVENCIÓN}

La Revolución francesa supone un punto de inflexión en la corriente migratoria, pues a los trabajadores habituales venidos a España habrá que sumar los exiliados -emigrados- por razones político-religiosas. Los enclaves portuarios serán la plataforma predilecta para que agentes subversivos franceses propalen las bondades revolucionarias mediante relatos orales, y sortearán de manera ingeniosa las medidas de control profiláctico decretadas por el Gobierno y los tribunales inquisitoriales introduciendo prensa, opúsculos y panfletos revolucionarios ${ }^{47}$. Tengamos en cuenta además que en el último tercio del s. XVIII se difunden imparablemente por los cafés y tertulias todo tipo de chismes, rumores, anécdotas picantes, relatos maliciosos y calumnias ${ }^{48}$ que hacen las delicias de la burguesía. En Cádiz, las autoridades cerrarán un club frecuentado por franceses que mostraban simpatías revolucionarias en sus reuniones. Las autoridades españolas estarán atentas a las posibles contaminaciones ideológicas a las que estaban expuestas las capas populares que entablaban contacto con los franceses. Lérida, en 1791, era zona de paso de miles de franceses que se desplazaban para trabajar en las almazaras del sur de Cataluña, Aragón y Valencia. Los franceses se jactaban ante los españoles de la mejora en la vida cotidiana debido a la sustancial rebaja de los gravámenes, el clima de libertad e igualdad y la exención de múltiples impuestos religiosos ${ }^{49}$.

decir, eran aprendices del oficio de comerciante y se formaban en las prácticas comerciales actuando como intermediarios en los negocios hasta poder establecerse de forma independiente. VILLAR GARCíA, María Begoña y GARcía MonToro, Cristóbal. «El capital mercantil en las crisis de principios del siglo XIX. Tres ejemplos malagueños». Baetica. Estudios de Arte, Geografía e Historia, 1989, 12, p. 267.

45. Coronas TejadA, Luis. "La burguesía...", op. cit., p. 176.

46. Uno de los oficios viles era el de hornero, lo que explica que, a finales del s. XVII, la mayoría de los oficiales panaderos de Jaén fuesen franceses. En la capital, la colonia francesa establecida en la segunda mitad del XVII será por regla general una minoría marginada por los trabajos desempeñados. Coronas Tejada, Luis. Jaén, siglo XVII. Jaén: Instituto de Estudios Giennenses, 1994, pp. 204-206.

47. La profilaxis también tendrá como objetivo a los profesores, pues el Santo Oficio retiró a la Universidad de Granada la bula papal que permitía a sus docentes tener y leer libros prohibidos. CALvO Maturana, A. J. "Narciso de Heredia: una carrera académica en la Universidad de Granada en tiempos de Carlos IV». Chronica Nova, 2003, 30, p. 51.

48. DARnTON, Robert. The Devil in the Holy Water, of the Art of Slander from Louis XIV to Napoleon. Penssilvania: University of Penssilvania-Press Penn, 2011.

49. FRASER, Ronald. La maldita guerra de España: historia social de la Guerra de la Independencia. 1808-1814. Barcelona: Crítica, 2006, pp. 18-19. 
Los emigrados serán firmes defensores de la monarquía absoluta, y durante la etapa de gobierno del conde de Aranda (antiguo embajador en Paris e incombustible francófilo), se organizarán en Madrid como grupo de presión (liderados por el duque de Havré y el conde de Vauguyon) para que Carlos IV declare la guerra a la Convención, incrementando sus presiones políticas en el último trimestre de $1792^{50}$. Aranda, descolocado por los acontecimientos, será acusado de inacción por los sectores más conservadores, y, a mediados de noviembre de 1792, caerá y será sustituido por Manuel Godoy. El valido extremeño será el responsable de organizar las acciones bélicas.

En 1793, la Guerra de la Convención o Guerra Gran, como se la conoció entonces, supuso la entrada en España de un contingente numeroso de refugiados franceses en busca de asilo para escapar del radicalismo jacobino. Con anterioridad al conflicto bélico, había censados en tierras hispanas alrededor de 80.000 franceses, que o bien estaban asentados desde hacía años o bien llegaron a partir de 1791, cuando se acelera la deriva revolucionaria gala. La alianza española con las monarquías absolutistas europeas, y el consiguiente envío de tropas para combatir a los revolucionarios en su propio país, motivó que se publicara un informe sobre la situación de los residentes franceses en España, dividiéndolos en cuatro grupos principales: banqueros, comerciantes, artesanos y "artistas». Y según la duración de su estancia, se establecían tres categorías: franceses naturalizados españoles (poco numerosos) ${ }^{51}$, transeúntes (los que acreditaban una estancia corta, caso de los temporeros) y avecindados, término reservado para los que estaban domiciliados y habían prestado juramento de sumisión a Carlos IV para disfrutar del permiso de ejercer con libertad su oficio ${ }^{52}$.

La Real Cédula de 20-VII-1791 tenía como objetivo controlar la colonia francesa y expulsar a los transeúntes, y mandaba hacer un censo o matrícula de extranjeros, obligados a jurar fidelidad al rey y a la Iglesia católica y a renunciar al fuero de extranjería, con lo que perdían su situación jurídica de privilegio comercial reconocida en los tratados, lo que motivó una progresiva desbandada de mercaderes franceses, sobre todo de Madrid y Cádiz, aunque no pocos aceptaron quedarse a través de la domiciliación y la naturalización. Los banqueros y financieros galos asentados en

50. La Parra López, Emilio. "La inestabilidad de la monarquía de Carlos IV». Studia Histórica. Historia Moderna, 1994, XII, p. 27. LoRENZO Álvarez, Elena de (coord.). La época de Carlos IV, (17881808): Actas del IV Congreso Internacional de la Sociedad Española de Estudios del Siglo XVIII. Gijón: Trea, 2009.

51. La adquisición de la nacionalidad española era un proceso complicado en el que debía acreditarse ante los informantes de la administración una buena conducta, unas prácticas religiosas intachables (será frecuente apuntarse en cofradías para demostrar este punto), una correcta integración social e incluso disponer de unas rentas suficientes. BARTOLOMEI, Arnaud. "La naturalización de los mercaderes franceses de Cádiz a finales del siglo XVIII y principios del XIX". Cuadernos de Historia Moderna, 2011, X, pp. 123-144.

52. AYMes, Jean René. La Guerra de España contra la Revolución francesa (1793-1795). Alicante: Instituto de Cultura Juan Gil-Albert, 1991, p. 241. 
Madrid y Cádiz también se resintieron (la mayoría abandonó el país), pues, al ser tenidos por sospechosos de propagar las ideas revolucionarias, fueron objeto de una campaña que mezclaba elementos de xenofobia, contrarrevolución y nacionalismo español, motivando que a varias compañías francesas se les retirasen sus privilegios comerciales en beneficio de otras hispanas, y, también, proporcionando excusas a los españoles para no satisfacer las deudas contraídas con los banqueros y comerciantes galos. Además, se depreció la deuda francesa, algo que perjudicó sobremanera al Banco Nacional de San Carlos, que había invertido fuertes sumas en ella.

Los acontecimientos acaecidos en el trienio 1789-1792 motivarían a finales de febrero de ese último año la caída del conde de Floridablanca, principal valedor otrora de los financieros franceses, decididos sustentadores de su anterior política reformista merced al capital aportado. Floridablanca, que desde el principio de su mandato se vio a sí mismo como un ministro confidente (del rey), mantuvo una postura de rechazo frontal a la Revolución francesa que le condujo a adoptar drásticas medidas para evitar que las miasmas revolucionarias infeccionasen a España, lo cual generó una espiral: se echó en brazos de los sectores reaccionarios, persiguió con ahínco a los franceses residentes sospechosos de simpatías revolucionarias, concedió todo tipo de facilidades para que se aposentasen en territorio español nobles y clérigos emigrados, tensionó hasta el extremo las relaciones diplomáticas con Francia y terminó perdiendo el favor del rey.

En líneas generales, las capas populares españolas mostraron actitudes de respeto y comprensión hacia los franceses instalados en las distintas poblaciones que no abandonaron España, pues éstos, mayoritariamente, repudiaban a los revolucionarios y no se arredraban en manifestarlo.

No obstante, hubo eventuales roces con los refugiados y protestas del pueblo llano por una mezcolanza de motivos: la competencia en los oficios, el recelo que despertaban los más empobrecidos (vivían de la caridad) y las consecuencias gravosas en la economía de las ciudades que los acogían al elevar los precios de los alimentos de primera necesidad (pan y vino) ${ }^{53}$ y otros abastos; incluso el clero secular protestó por la subida de la harina para elaborar sagradas formas y del vino de consagrar ${ }^{54}$.

La red de espías galos, los cónsules franceses y los comerciantes de dicho país que simpatizaban con la Convención difundían el ideario revolucionario y se enfrentaban con sus compatriotas emigrados realistas exhibiendo escarapelas tricolores y otros símbolos, lo que exacerbaba los respectivos odios, que estallaban en episodios de violencia, como sucedió varias veces en Barcelona.

53. Así ocurrió en las zonas fronterizas con Francia, Benito AgUado, Teresa. "Proyecto político y constitución social en Álava. Comunidad política y territorio ante la Guerra de la Independencia”. Sancho el Sabio, 2012, 35, p. 233.

54. Benito Aguado, Teresa. La sociedad vitoriana en el siglo XVIII: el clero, espectador y protagonista. Bilbao: Universidad del País Vasco, 2001, pp. 370-389. 
Pero, de manera paradójica, los clérigos exiliados terminaron provocando hastío, pues su incombustible celo antirrevolucionario se entreveraba con críticas de los usos cotidianos de los españoles, de su incultura, su ausencia de vida social y la carencia de diversiones sanas. Estos dardos escocieron tanto al pueblo llano que revertió su inicial comprensión hacia los religiosos y los consideró una pesada carga económica debido a su improductividad laboral ${ }^{55}$. Se habían convertido en un fardo.

Los conatos de violencia antifrancesa, los asaltos a propiedades o los atentados personales fueron escasos, fruto siempre de altercados que buscaban un chivo expiatorio y que estuvieron ocasionados por la virulenta propaganda (difundida sobre todo desde los púlpitos), o bien, se dirigieron contra franceses que no se recataron de exhibir simpatías revolucionarias. Los principales conflictos de este tipo acontecieron en Barcelona, País Vasco y Valencia (en la ciudad levantina se saquearon las casas de los franceses, se recluyó a 394 en la Ciudadela para evitar su apaleamiento y 326 fueron expulsados) ${ }^{56}$, mientras que en otros lugares los problemas de convivencia surgieron por la desfachatez de algún francés por declararse adicto a la Revolución, ver con buenos ojos la ejecución en la guillotina de Luis XVI, confraternizar con los soldados franceses prisioneros repartidos por diferentes ciudades, dar gritos a favor de la libertad o atacar algún aspecto de la Iglesia. Así, ocasionales disturbios -de baja intensidad- hubo en Madrid, Lorca, Alcalá de Henares, Mérida, La Coruña, Ferrol, Cádiz y Málaga ${ }^{57}$.

También se dieron casos de emigrados enrolados en el Ejército, caso del Regimiento de Borbón acuartelado en la ciudad de Palma, donde habían sentado plaza 605 franceses a finales del s. XVIII ${ }^{58}$.

Dentro de los emigrados destacarán, como ya hemos visto, los clérigos, por su abundancia (unos 6.000) y por su extrema repulsa del ideario revolucionario ${ }^{59}$. Los exiliados religiosos tendrán que cumplir -en teoría- unas medidas legislativas tendentes a controlar su situación en España: prohibición de residir en Madrid y

55. La Parra López, E. Manuel Godoy. La aventura del poder. Barcelona: Tusquets, 2002, p. 162.

56. El arzobispo de Valencia, Francisco Fabián y Fuero, acogió a varios cientos de religiosos huidos, destacando cuatro monjas ursulinas que fueron alojadas en la Casa de Enseñanza, donde se dedicaron a dar clase a las alumnas que había. El capitán general ordenó en la Navidad de 1793 la expulsión de todos los franceses residentes en el reino valenciano, a excepción de las francesas casadas con españoles. El anciano arzobispo alegó inmunidad en la jurisdicción eclesiástica para no deportar a las ursulinas francesas, lo que provocó enfrentamientos con los militares y la renuncia del arzobispo tras su novelesca huida de Valencia en enero de 1794 para no ser detenido por los soldados. Pero previamente, en marzo de 1793, hubo episodios de gran violencia contra los franceses establecidos profesionalmente en la ciudad del Turia. Véase AlBerola Romá, Armando y Giménez López, Enrique. "Los alborotos antifranceses de Valencia y la huida del arzobispo Fabián y Fuero". Studia Historica, 1994, 12, pp. 91-113.

57. AYmes, Jean René. La Guerra de España..., op. cit., pp. 242-250.

58. FERRER FLórez, Miguel. "Represión de franceses en Mallorca (1808-1809)». Bolletí de la Societat Arqueològica Lul-liana: revista d'estudis històrics, 1997, 53, p. 192.

59. Sierra, Luis. "La inmigración del clero francés en España». Hispania, 1968, 109, pp. 393-421. 
en las capitales de provincia, no poder establecerse a menos de veinte leguas de la frontera pirenaica, no predicar, no dar clases en colegios ni alojarse en casas privadas. Estos refugiados, por motivos ideológicos y humanitarios, levantarán en un primer momento simpatías entre los españoles (no eran competidores de ninguna profesión civil), y recibirán ayuda de los obispados y el clero hispano para establecerse por muchas diócesis, aunque se producirán alborotos como el de Granada en mayo de 1793, cuando unos agitadores lancen a las masas (jóvenes y mujeres, sobre todo) contra sacerdotes emigrados que, a pesar de vivir en la miseria, eran vistos como detestables franceses a los que había que linchar, pidiendo incluso la horca para ellos.

Como la Francia jacobina se vaciaba de clérigos que entraban en oleadas en España, para evitar problemas de acogida y disturbios, en diciembre de 1793 los capitanes generales recibieron órdenes de impedir la entrada de más religiosos franceses y exhortaron a los diferentes obispados a retener a los exiliados que tenían y que les negasen permiso para trasladarse a otra diócesis.

A partir de 1790 las diócesis de Calahorra y Pamplona reciben un incesante flujo de religiosos emigrados refractarios (contrarios a aceptar el juramento cívico de los principios revolucionarios), casi todos procedentes del oeste y suroeste de Francia, puntos geográficos donde se registrarán importantes levantamientos contrarrevolucionarios. La diócesis de Calahorra acogerá a 1.477 clérigos, la de Valencia a 618 y el arzobispado zaragozano a $115^{60}$. El $80 \%$ de los clérigos rechazaron el juramento (bajo instrucciones del papa) y optó por el exilio. La mayoría llegaba en condiciones tan precarias que las autoridades civiles y eclesiásticas se quejaban de los gastos de manutención que ocasionaban, y, además, hubo que recogerlos en conventos para evitar la propagación de relatos de lo que sucedía en su país ${ }^{61}$, en Paris y en la Vendée, donde las matanzas de campesinos y religiosos alcanzaron una proporción descomunal ${ }^{62}$. Sin embargo, los frailes españoles, al limosnear y predicar extramuros conventuales, se encargarán en los años sucesivos de propagar y amplificar los relatos que escucharon de boca de sus hermanos emigrados, por lo que las clases populares de todos los pueblos desarrollaron a partes iguales recelo y odio contra la Francia revolucionaria, lo que coadyuvará a explicar el estallido antifrancés de 1808 y el papel protagonista del clero regular para municionar mentes y almas patriotas.

60. Lebourleux, André. "Les pêtres du diocèse de Bayonne emigrés dans la diocèse de Calahorra pendant la Révolution Française». Kalakorikos, 15, 2010, pp. 223-274.

61. Artola Renedo, Andoni. «La antimodernidad en el País Vasco: prácticas sociales y discursos (1765-1833)». Cuadernos Dieciochistas, 2009, 10, p. 132.

62. Un estudio de la influencia de la guerra vendeana en el centón decimonónico en nuestro país puede verse en CASPISTEGUI, F. J. "La Vendée en las culturas políticas de la España decimonónica». Memoria y civilización, 2012, 15, pp. 319-336. Un interesante análisis de las matanzas vendeanas y de otras formas de aniquilación colectivas perpetradas por los jacobinos es el de Burleigh, M. Poder terrenal. Religión y política en Europa. Madrid: Taurus, 2006, pp. 119-130. 
La diócesis de Bayona se vació de religiosos, los cuales eligieron las tierras vascas y navarras como lugar de exilio por razones idiomáticas (muchos hablaban vascuence) y por los lazos de parentesco con las familias que vivían más allá de los Pirineos. Las posiciones contrarrevolucionarias de estos clérigos refractarios influirán en el robustecimiento de un discurso político y de unos usos sociales antimodernos en el territorio vasco ${ }^{63}$ en particular y en el resto de España en general ${ }^{64}$. La primera oleada de emigrados tuvo una acogida favorable por todos los estamentos españoles, comenzando por el propio rey, algo que Godoy trató de frenar por el temor a que entre tantos religiosos refugiados se infiltrasen revolucionarios que instilasen su peligroso ideario en España.

El obispo de Orense, Pedro de Quevedo, dispensó una cálida acogida a más de 300 religiosos refractarios, los cuales, por su animosidad contrarrevolucionaria, serán vigilados por agentes franceses de la Convención enviados a Galicia. Así, el cónsul D'Hermand informa que en octubre de 1792 llegan a La Coruña 210 clérigos galos que se dedicarán a criticar acerbamente a los revolucionarios. Dichos religiosos franceses celebrarán en febrero de 1793, en todas las poblaciones donde estén instalados, exequias por el alma de Luis XVI, e incluso el 25 de noviembre de 1793, oficiarán un oficio fúnebre en la catedral compostelana en recuerdo de María Antonieta ${ }^{65}$.

Jaén también fue tierra de promisión para muchos emigrados civiles y religiosos. Los primeros se integraron sin mayores problemas con la población autóctona y los segundos fueron bien tratados por el obispo Agustín Rubín de Ceballos: de los 82 clérigos acogidos, el 35\% se quedó en la capital y el resto fue repartido por el cabildo catedralicio por conventos de la diócesis. Todos estos expatriados llegaron en una extrema situación de pobreza. A partir de 1795 casi todos los refugiados religiosos regresaron a su país. En 1793 fueron expulsados de la ciudad 53 franceses civiles (eran o transeúntes o solteros o viudos sin cargas familiares) y se quedaron los que estaban casados con francesas o españolas ${ }^{66}$.

Tras la Paz de Basilea (1795) y el Tratado de San Ildefonso (1796) se normalizan las relaciones entre ambos países, se restaura la hegemonía francesa en el continente, la Corona española vuelve a supeditarse a los intereses políticos y económicos de Francia y retornan a España bastantes mercaderes y financieros franceses, devolviéndoles la Real Hacienda los bienes embargados. Serán, sobre todo, comerciantes de rango intermedio y bajo los que se hallen a finales del $s$. XVIII y comienzos del s. XIX. Hacia Castilla se encaminaron franceses de la región

63. ARTOla Renedo, Andoni. "La antimodernidad...", op. cit., pp. 121-147.

64. RAmón SOlans, Francisco Javier. «Conjugando los tiempos presentes. Figuras temporales de la contrarrevolución española (1789-1814)». Historia y Política, 2012, 28, pp. 215-243.

65. Juana, Jesús de. "Reacción en Galicia ante la Revolución y la ocupación francesa». En DE DiEGo, Emilio (coord.). Repercusiones de la Revolución francesa en España. Actas del Congreso Internacional. Madrid: Universidad Complutense, 1989, pp. 393-402.

66. CORONAS TejadA, Luis. "Aspectos socioeconómicos de la inmigración francesa en Jaén (17501834)». En Villar García y Pezzi Cristóbal (eds.). Los extranjeros..., op. cit., pp. 279-287. 
de Auvernia para reorganizar sus sociedades mercantiles, mientras que los naturales de la región de Bearn prefirieron instalarse en Aragón ${ }^{67}$. A partir de entonces, será una práctica usual castellanizar los nombres franceses para buscar una rápida asimilación e integración social, así como los matrimonios mixtos ${ }^{68}$, aunque estos enlaces no eran infrecuentes desde mediada la centuria.

\section{LOS ANTIGUOS EMIGRADOS: ¿UNA QUINTA COLUMNA AFRANCESADA EN 1808?}

Al iniciarse la Guerra de la Independencia, ¿qué hicieron estos franceses afincados en España, muchos de ellos casados? Los antiguos emigrados y sus hijos compartían por lo común un ideario contrarrevolucionario (fruto de su amarga experiencia personal) retroalimentado por la evocación de recuerdos y el temor a las hipotéticas represalias que pudiesen adoptar contra ellos los invasores imperiales en 1808. La aceleración del tiempo histórico experimentada desde 1789 supuso un brusco cambio en todos los órdenes, una dramática ruptura con el pasado, y los exiliados carecían de otras referencias políticas en su marco vital, lo que les generó un gran miedo al porvenir que se mantuvo hibernado y despertó en 1808.

Lo cierto es que los exiliados no actuaron como quintacolumnistas que favorecieran la caída de ciudades sitiadas mediante transmisión de información a las tropas imperiales, ni tampoco cooperaron activamente con la administración bonapartista en las prefecturas y municipalidades ocupando cargos de responsabilidad o enriqueciéndose comercial o financieramente. Es más, hay ejemplos de emigrados que combatieron codo con codo con soldados y voluntarios patriotas enfrentados a los regimientos napoleónicos, como sucedió en Jaén ${ }^{69}$, Badajoz ${ }^{70}$ y

67. Salas Auséns, José Antonio. «Leyes de inmigración y flujos migratorios en la España Moderna». En Villar García, M. B. y Pezzi Cristóbal, P. (eds.). Los extranjeros en la España Moderna. I Coloquio Internacional. Málaga, 2003, p. 645.

68. En Jaén, en 1796, constaban los casamientos mixtos de Juan Francisco Camps con Ramona López (procedentes de Cuenca), Blas Ferro con la sevillana Eusebia de León, Juan Esponera con la jiennense Joaquina Delgado, Pedro Pasquau con Catalina Delgado (Jaén) y Juan Pedro Forcada con la jiennense Salvadora Ruiz. CORONAS TeJADA, Luis. "La burguesía mercantil de Jaén en el primer tercio del siglo XIX». Boletín del Instituto de Estudios Giennenses, 1993, 150, pp. 175-190.

69. Fue el caso de Jaén. Juan Bautista Fromajet de Bandeville, un emigrado francés cuyo padre, mayordomo de Luis XVI, fue ejecutado por los jacobinos. Durante los días 1, 2 y 3 de julio de 1808, un pequeño contingente napoleónico emprendió una acción punitiva contra Jaén y hubo combates contra las milicias urbanas y los soldados regulares que se saldaron con la retirada de los imperiales tras el infructuoso intento de saquear la capital. Juan Bautista Fromajet combatió en diversos puntos de la ciudad, lideró a varios soldados en los tiroteos y fue herido de un balazo en un brazo. Diario de Jaén, martes 26 de julio de 1808, p. 40. La familia de Gracián Berges también luchará contra sus antiguos compatriotas, según LóPEz PÉREZ, Manuel y LARA MARTín-PORTUGuÉs, Isidoro. Entre la guerra y la paz. Jaén (1808-1814). Granada: Universidad de Granada, 1990, pp. 105-120.

70. En el asalto a la ciudad pereció el coronel Bassecourt, que junto a dos hermanos se integró en 1796 en la Guardia Valona. VALDÉs FERnÁNDEZ, Fernando. La Guerra de la Independencia en Badajoz. Fuentes francesas. Memorias. Badajoz: Diputación de Badajoz, 2003, p. 158. 
Alicante, donde el comandante imperial encarceló a dos hermanos franceses, Juan Antonio y Manuel Lattur, por antinapoleónicos. Y aunque hubo casos de antiguos exiliados que cooperaron con los ocupantes, podemos hacer el siguiente juego de palabras: hubo pocos franceses afrancesados y bastantes franceses patriotas.

La anterior aseveración puede aplicarse a 1814, en el marco de las depuraciones contra los sospechosos de haber colaborado con el gobierno intruso. Así, en Santander, fueron varios los franceses (casi todos casados con españolas) sometidos a este tipo de juicios políticos, y sólo consta que uno saliera malparado: Juan, el tejedor francés, que marchó con los imperiales al exilio. En dichos procesos depurativos santanderinos también se censuró a comerciantes franceses como Diego Redonet, cuya tienda servía para celebrar tertulias afrancesadas e incluso pretendía que en la pescadería se colocase una lápida en honor de José $\mathrm{I}^{71}$. En Jaén, el joven literato Manuel Bergeira, hijo de un antiguo emigrado casado con una española, tendrá que huir a Francia con las tropas imperiales y exiliarse allí por miedo a las represalias de sus convecinos, que lo convertirán en un chivo expiatorio mientras su padre, el comerciante Juan Pedro Bergeira, se quedará en la capital jiennense interviniendo a favor de su hijo en el proceso judicial de depuración política ${ }^{72}$.

Y la sociedad española, ¿qué actitud mostró hacia los viejos exiliados y sus descendientes? Las situaciones fueron diversas, y bascularon entre la inicial desconfianza y la violencia física, los saqueos de sus propiedades o el embargo de sus bienes. Hubo ciudades donde los cabildos municipales o la autoridad militar recluyeron en mayo de 1808 a la colonia francesa con una ambivalente finalidad: controlarla políticamente y resguardarla de ataques de exaltados. Pasados los dos primeros meses del levantamiento popular, por lo general, se abandonarán los recelos y no se considerará a los emigrados como el enemigo en casa, aunque habrá excepciones y la niebla de recelo y sospecha hacia ellos no se disipará. Aunque la situación cambiará a comienzos de 1809...

Una vez difundidas por toda la nación las noticias de los sucesos de Madrid el 2 de mayo, se produjo un efecto dominó y los levantamientos locales durante los meses de mayo y junio respondieron a diversas causas -yuxtapuestas en muchas ocasiones-, pero que podemos clasificar en dos tipos: alzamientos populares y espontáneos (la mayoría, nada más tener noticia de los sucesos madrileños) y los organizados (a finales de mayo), que reactivaron la vieja y larvada pugna entre godoyistas y fernandinos: hubo ciudades donde la movilización popular aparejó la deposición de las autoridades colocadas por Godoy. Los patriotas ${ }^{73}$ interpretaron

71. GuERRERO ELECALDE, Rafael. "Colaborar con el invasor. Los afrancesados cántabros durante la Guerra de la Independencia”. Monte Buciero, 2008, 13, pp. 201-203.

72. Archivo Municipal de Jaén: Libro de Actas Capitulares, sesión de 5 de noviembre de 1818.

73. Azanza dirá en su Memoria Justificativa de 1814 que los adversarios patriotas eran el «bando nacional», "los nacionales». 
la invasión francesa como un atentado contra la Monarquía, la Religión y sus inveteradas formas de vida. El levantamiento armado fue de abajo arriba: el pueblo llano forzó a las autoridades civiles y militares a declarar la guerra y a movilizar tropas, y cuando creyó detectar tibieza o inactividad en las élites gubernativas se desataron episodios de inusitada violencia que acabaron con la vida de corregidores, nobles o militares ${ }^{74}$. Las movilizaciones populares desbordaron los órganos de poder del Antiguo Régimen al forzar a sus integrantes a organizarse militarmente en juntas, a dar una respuesta política contundente y a coordinar el esfuerzo bélico, creando una situación revolucionaria en la que las élites civiles, militares y eclesiásticas fueron a remolque de la acelerada sucesión de acontecimientos.

Al socaire de los levantamientos antedichos, los odios de las clases populares y el revanchismo social estallaron contra algunos franceses domiciliados en bastantes urbes a partir del Dos de Mayo: fueron los cabezas de turco. En ocasiones, como en Zaragoza (donde había casi un millar a comienzos del primer sitio), las autoridades locales pensaron que podían ser una quinta columna, y para desactivar una hipotética ayuda a los soldados napoleónicos, los recluyeron en la Aljafería (la cárcel de la Inquisición). En Mallorca el odio soterrado se canalizó asaltando las casas comerciales de origen francés (Canut y Mugnarot) y presionando a la recién constituida Junta Suprema para que expulsase a algunos miembros acusados de francofilia ${ }^{75}$. En la provincia de Alicante se exhortó en mayo a los franceses a no exhibir la escarapela tricolor y a moderar sus opiniones políticas. La Junta de Represalias constituida en Jijona ordenó encarcelar a un francés y embargar sus bienes por apoyar a Napoleón. En Elche, el 6 de junio se detuvo a cuatro franceses y se embargaron sus posesiones, y en Denia, a los comerciantes franceses se les exigieron contribuciones de guerra ${ }^{76}$.

En la capital alicantina se envió al cónsul francés a las mazmorras del castillo de Santa Bárbara y la colonia gala (96 hombres) fue recluida en diferentes recintos con el pretexto de salvaguardar sus vidas, y sus bienes fueron confiscados como medida preventiva. Los centros habilitados para recluirlos fueron: la Casa de la Misericordia, la Casa Asegurada y la Real Cárcel. Se creó una Junta de Tranquilidad Pública para mantener el orden, y los alborotos cesaron hasta que el 26 de agosto los encarcelados fueron liberados, pero, debido a los tumultos, los franceses volvieron a ser encerrados y se apaciguaron los ánimos prometiendo su inminente

74. Entre mayo y junio de 1808 resultaron asesinados los corregidores de Jaén, Huesca, Manresa y Villena. En Valladolid fue ahogado en las aguas del Esgueva el director de la Escuela de Artillería de Segovia, en La Coruña y Badajoz mataron a los respectivos gobernadores militares, y fueron apaleados hasta la muerte generales en Cartagena y Cádiz.

75. FERre FlóRez, Miguel. "Transformación ideológica en Mallorca». Memòries de la Reial Acadèmia Mallorquina d'Estudis Genealògics, Heràldics i Històrics, 2008, 18, p. 81.

76. MuÑOZ LORENTE, Gerardo. La Guerra de la Independencia en la provincia de Alicante (18081814). Alicante: Editorial Club Universitario, 2009. ÁlvareZ y CAÑAS, María Luisa (coord.). La Guerra de la Independencia. Alicante (1808-1814). Alicante: Instituto de Cultura Juan Gil-Albert, 2010. 
destierro. Así, el 4 de septiembre se ordenó el extrañamiento de los franceses transeúntes (eran el grueso de la colonia, y escasos sus recursos económicos) por considerarlos "adictos al pabellón de su nación", y fueron obligados a embarcar en un buque que los condujo a Francia y a Gibraltar ${ }^{77}$. Sólo quedó en Alicante un puñado de franceses domiciliados, casados con españolas y con hijos.

En Ciudad Rodrigo, el 10 de junio de 1808 una enardecida muchedumbre da muerte, entre otras personas, al comerciante francés Juan Bayle, siendo su cadáver arrastrado por las calles.

La isla de Mallorca fue un caso especial, pues a la relativamente importante colonia de emigrados hay que sumar el paulatino envío de prisioneros franceses desde la Península a lo largo de 1808. Los mallorquines expresan sus sentimientos antifranceses mediante manifestaciones, pasquines y artículos de prensa que piden el encarcelamiento de todos los exiliados, a excepción de los oficiales del Regimiento de Borbón. Las casas comerciales francesas son sometidas a una estrecha vigilancia y se revisa su correspondencia, y en enero de 1809, son recluidos los emigrados isleños militares y civiles (alrededor de 70). En abril unos cuantos serían liberados, pero ya no se los trató con hospitalidad, pues las sospechas les ocasionarían continuas molestias, vejaciones y persecuciones ${ }^{78}$.

Los sucesos más luctuosos ocurrieron en Castellón y Valencia ${ }^{79}$ entre mayo y junio, cuando las encendidas masas, acaudilladas por dos religiosos (primero el franciscano de Monóvar Juan Rico Vidal, y luego el canónigo de San Isidro de Madrid, Baltasar Calvo), asesinaron a unos cuatrocientos franceses, muriendo la mitad la noche del 5 de junio, hasta que las autoridades valencianas impusieron el orden.

En Málaga, a mediados de mayo unos incontrolados sacaron del castillo de Gibralfaro al vicecónsul francés en la ciudad D’Argaud y a un compatriota, Juan Crohare (recluidos días atrás para evitar su linchamiento), y se ensañaron con ellos hasta darles muerte ${ }^{80}$.

En Almería, donde existía un grupo de franceses, siguiendo órdenes de la Junta de Sevilla, en enero de 1809 se decreta su encarcelamiento en el Cuartel de la Misericordia aunque no se les embargan los bienes. Permanecerán presos hasta junio, cuando sean puestos en libertad, si bien serán vigilados ${ }^{81}$.

77. Álvarez Cañas, María Luisa. La Guerra de la Independencia en Alicante. Alicante: Patronato Municipal del 5. ${ }^{\circ}$ Centenario de la Ciudad de Alicante, 1990, pp. 62-81.

78. FERRER Flórez, Miguel. «Represión...», op. cit., pp. 204-212.

79. Hernando Serra, María Pilar. El ayuntamiento de Valencia y la invasión napoleónica. Valencia: Universidad de Valencia, 2004, pp. 85-100.

80. Reder Gabow, Marion y Pérez Frías, Pedro L. "La Guerra de la Independencia en VélezMálaga y en la Axarquía: guerrillas y contraguerrillas». Baetica. Estudios de Arte, Geografía e Historia, 2009, 31, p. 413.

81. Se trataba del panadero Josef Borduin, el bodeguero Juan Castañier, el carnicero Juan Polvorell y los caldereros Juan de Fox, Luis Casaña y Luis Labro. CASTILlo CANO, José. Almería en la crisis 
En Jaén, en los ataques de las tropas napoleónicas durante los tres primeros días de julio de 1808, colaboraron con los atacantes varios franceses residentes: unos cuantos huyeron con los batallones de casacas azules cuando se replegaron, y otros fueron encarcelados ${ }^{82}$. El 10 de enero de 1809 son encerrados en presidio los 70 franceses que residían en la ciudad (muchos eran panaderos y otros comerciantes textiles), dilatándose su cautiverio durante semanas.

En el pueblo jiennense de Linares el eco del Dos de mayo originó un episodio de picaresca: el pregonero, Antonio Abadía, intentó estafar a Bárbara la francesa exigiéndole veinte duros para comprar armas para luchar contra los franceses ${ }^{83}$. Como la mujer no se avino al chantaje y además fue defendida por un vecino, el pícaro pregonero linarense se subió a un balcón de la casa capitular y trató de soliviantar a la gente invocando la guerra santa. El corregidor lo metió en la cárcel.

\section{LOS AFRANCESADOS DE 1808: CARACTERÍSTICAS Y PRECISIONES SEMÁNTICAS}

Ante todo hay que resaltar que el afrancesamiento al que nos referimos se trata de un fenómeno sobrevenido, pues con anterioridad a la invasión napoleónica de España en 1808 no existía ningún grupúsculo político afrancesado, es decir, un sector más o menos cohesionado que reclamase un volantazo a la monarquía borbónica en el sentido de asemejarse al régimen bonapartista del país vecino. Las abdicaciones de Bayona y la consiguiente entrega de Napoleón de la Corona española a su hermano mayor José ${ }^{84}$ serán los acontecimientos fundacionales del afrancesamiento político: el conjunto de personas que, por convicción, se identificaron con la monarquía bonapartista al creer que modernizaría las anquilosadas instituciones y estructuras políticas borbónicas. El cambio dinástico y de régimen auguraba un futuro esplendente.

Aunque no hay que desdeñar sus simpatías ideológicas con el régimen de Bonaparte en Francia, ante todo eran pragmáticos que, dada la acelerada sucesión

del Antiguo Régimen: la Guerra de la Independencia en la ciudad (1797-1814). Almería: Diputación Provincial de Almería, 1987, pp. 115-116.

82. Se trató de Juan Pablo Casanova, Juan Pedro Bergeira, Juan Esponera (y su mujer) y Manuel Bergeira. LóPEz PÉREz y LARA MARTíN-PORTUGuÉs. Entre la guerra..., op. cit., p. 237. Juan Esponera y sus tres sobrinos serían juzgados el 30 de julio de 1809 por la antedicha cooperación.

83. Bárbara Ocofoux, de 47 años, regentaba una especiería desde 1807. Casada con un español, enviudó en 1809 y en 1811 casó en segundas nupcias con Diego Sarao. Nunca más será molestada por el vecindario. López Gallego, Félix. «Un manuscrito inédito: Apología de las guerrillas o idea del Vergantismo. Participación de la villa de Linares durante la Guerra de la Independencia». Elucidario, 2008, 6, p. 242.

84. Respecto a los litigios paternofiliales tras el motín de Aranjuez y el intento de sustanciarlos ante Napoleón en calidad de mediador que acabaron con la cesión de la Corona a éste, "lo acordado el 6 de mayo de 1808 no pasaba de un simulacro de legalidad, simple cobertura de una imposición externa”, según Morán OrTí, Manuel. «La formación de las Cortes (1808-1810)». En ArTOla, Miguel (ed.). Las Cortes de Cádiz. Madrid: Marcial Pons, 2003, pp. 13-14. 
de acontecimientos en la primavera de 1808, y ante el pánico al desorden social provocado por un vacío de poder, optaron por su adhesión a una forma de monarquía en la persona de José I, rey cuyo programa renovador se inspiraba en el reformismo ilustrado más las aportaciones de cuño napoleónico salvaguardadas de la Revolución francesa.

El afrancesamiento no fue un movimiento homogéneo, pero el cemento ideológico que los aglomeraba estaba compuesto por varios ingredientes: la convicción de que era inútil resistirse al invencible ejército francés y al genio militar del emperador, la apuesta por la monarquía como forma de gobierno (no eran republicanos), la defensa de la ley y el orden y la imperiosa necesidad de introducir reformas políticas de calado en España. Hijos del despotismo ilustrado, eran atemperados ideológicamente y denostaban al populacho por su irracionalidad, sus creencias atávicas y sus nulas condiciones para participar en la toma de decisiones políticas ${ }^{85}$. Todos ellos eran conscientes de que, una vez finiquitada la dinastía borbónica, urgía modernizar un Estado inoperante ${ }^{86}$. "Regeneración» era la palabra clave para ellos, entendida como la realización de reformas profundas sin deslizarse por el plano inclinado que conducía a la revolución ${ }^{87}$.

Sin embargo, sería conveniente matizar que la inclinación de los afrancesados por la monarquía bonapartista no se debió sólo a un sincero patriotismo y un altruista deseo de cambio de régimen. Con agudeza, el profesor Emilio de Diego sostendrá que los afrancesados «se han convertido en la encarnación de todas las bondades por un sector de nuestra historiografía " ${ }^{88}$ y que los tópicos sobre ellos siguen aún vigentes, pues fue un colectivo heterogéneo. Las biografías aportan las claves para entender su posicionamiento ideológico, como es el caso de la del coronel Francisco Amorós, en la que queda patente que este militar y profesor de educación física de ideas avanzadas encontró en la nueva monarquía josefina el sistema óptimo para continuar trabajando al servicio de la administración y materializar sus afanes pedagógicos ${ }^{89}$. E, igualmente, Gérard Dufour, al estudiar al religioso Juan Antonio Llorente, explica cómo halló en el régimen de José I la manera de encumbrarse (sufría de insuficiencia mitral, es

85. Dufour, Gérard. "Los afrancesados o una cuestión política: los límites del despotismo ilustrado». Cuadernos de Historia Moderna, Anejos, 2007, VI, pp. 269-277.

86. López TABAR, Juan. "Incubando la infidencia. Afrancesados entre las élites políticas del Carlos IV». En Morales Moya, Antonio (coord.). 1802, España entre dos siglos. Volumen 2 (Monarquía, Estado, Nación). Madrid: Sociedad Estatal de Conmemoraciones Culturales, 2003, pp. 127-154.

87. López TABAR, Juan. "El fracaso de la tercera vía. José I y los afrancesados (1808-1813)». En Pérez Garzón, Juan Sisinio (ed.). España, 1808-1814. De súbditos a ciudadanos. Volumen II (Tomo I, segunda parte). Toledo: Junta de Comunidades de Castilla-La Mancha, 2008, pp. 29-48.

88. DiEGo, Emilio de. "La Guerra de la Independencia. Un balance en su Bicentenario». Cuadernos de Historia Moderna. Anejos, 2010, IX, p. 241.

89. FERnÁNDEZ SIRVENT, Rafael. Francisco Amorós y los inicios de la Educación Física moderna. Biografía de un funcionario al servicio de España y Francia. Alicante: Universidad de Alicante, 2005. 
decir, estaba dolido por no haber sido obispo), de enriquecerse y de aplicar su ideario reformista eclesial ${ }^{90}$.

En efecto, los ministros, consejeros de Estado, altos funcionarios, militares y clérigos afrancesados tomaron postura por una concomitancia de factores difícilmente separables: patriotismo (fueron la otra España) ${ }^{91}$, interés personal (para seguir disfrutando de sus privilegios, controlar las palancas del poder de un Estado centralizado o escalar puestos), inercia funcionarial, miedo ante los desmanes de la chusma (la canalla, llamó Murat a los madrileños alzados el Dos de mayo) revestido de prudencia conciliadora, resignación ante el poderío militar imperial, evitación de más derramamiento de sangre de compatriotas, ilusión por la erección de un nuevo régimen político sustituto de uno anterior considerado fracasado, defensa de la integridad nacional y deslumbramiento ante la figura áulica de Napoleón y el nuevo sistema político construido por él en media Europa. Casi todos esos motivos, durante su posterior exilio ${ }^{92}$, fueron alegados en sus escritos para justificar su adhesión al partido de José I.

A todo esto podría añadirse un elemento ilusionante: la posibilidad de hacer carrera profesional en el nuevo régimen mediante la meritocracia. La monarquía de Carlos IV frenó la fuerte movilidad social que caracterizó el reinado de Carlos III. Esta sensación de imposibilidad de ascenso profesional por parte de hombres preparados era una realidad sociológica, de modo que las categorías sociales procedentes del comercio o del Derecho ya no podían incorporarse a las élites del reino, lo que provocaría en 1808 una enquistada frustración social93. Los aires nuevos de la monarquía bonapartista eran una oportunidad para quienes ansiaban destacar merced al mérito y la capacidad, consagrados en el Estatuto de Bayona.

Pero, además, hay que tener presente que los afrancesados vivieron, diríamos hoy, una realidad virtual y en una constante hemiplejia: debido a la situación bélica, trabajaban en la construcción de un Estado que en muchos aspectos existió sólo sobre el papel, y como la administración josefina estaba en la práctica supeditada al omnímodo poder de los mariscales y generales franceses (en el plano político, militar y económico), que se comportaban como verdaderos virreyes al servicio directo del emperador, los afrancesados actuaban como si las autoridades francesas y sus tropas no sometiesen a gravosas exacciones fiscales a sus compatriotas españoles, ni los ajusticiasen, ni los represaliasen ni matasen en el campo

90. Dufour, Gérard. Juan Antonio Llorente. El factótum del Rey Intruso. Zaragoza: Prensas de la Universidad de Zaragoza, 2014.

91. López TABAR, Juan. "José I y los afrancesados. Otra España posible». En SALvador Benítez, Antonia (dir.). De Aranjuez a Cádiz: por la libertad y la Constitución. Aranjuez: Marañón-Ayuntamiento de Aranjuez, 2010, pp. 147-188.

92. Barbastro GIL, Luis. Los afrancesados. Primera emigración politica del siglo XIX español (1813-1820). Alicante: Instituto de Cultura Juan Gil-Albert, 1993.

93. LuIs, Jean-Philippe. "Cuestiones sobre el origen de la modernidad política en España (finales del siglo XVIII-1868)». Jerónimo Zurita, 2009, 84, p. 260. 
de batalla o en acciones punitivas antiguerrilleras ${ }^{94}$. O en todo caso, los afrancesados, conscientes de que coexistían dos realidades paralelas (la administración josefina y la militar francesa) que se manifestaban en un poder asimétrico, asumían que en primer lugar era necesario ganar la guerra contra el bando fernandino para después recoger los frutos de la benéfica monarquía bonapartista. La España bonapartista será la historia de una bicefalia imperfecta: por un lado, la etérea administración josefina, por otro, los territorios controlados por los generales franceses, prevaleciendo en última instancia el poder de éstos.

En un primer momento, el alto clero se avino a reconocer al nuevo soberano por considerar legítima la fórmula de traspaso de la Corona y por el miedo a las alteraciones sociales, de manera que afrancesados de primera y última hora fueron los religiosos mejor formados, concentrados en los cabildos catedralicios y en los sillones episcopales ${ }^{95}$. La burguesía, el sector más dinámico socialmente, tampoco mostró una prematura oposición al monarca, más bien lo contrario. Y el estamento castrense, acostumbrado a cumplir órdenes de sus superiores, se excusó en la obediencia debida y no hubo ruido de sables en los acuartelamientos contra el nuevo monarca... hasta que estallaron los alzamientos populares. Los afrancesados, por consiguiente, fueron, sobre todo: militares, intelectuales, juristas, funcionarios de rango medio o elevado y el alto clero más cultivado ${ }^{96}$.

Planteemos ahora una cuestión no baladí: la semántica. ¿Cómo llamarlos? Durante la guerra e inmediata posguerra, se les denominó de varias maneras, albergando todos los vocablos una carga despectiva: afrancesados, infidentes, napoleonistas, traidores, juramentados, josefinos, josefistas, cooperantes, renegados. ¿Todas esas palabras son válidas para los historiadores? ¿Acaso no esconden matices?

Miguel Artola acuñó en 1953 la división bipartita entre afrancesados y juramentados (o colaboracionistas) que ha arraigado en la historiografía y que damos por válida ${ }^{97}$. Los afrancesados se adhirieron a la nueva monarquía de manera libre y espontánea, convencidos de que era la mejor solución para la tesitura española, y prestaron un total apoyo político a la política reformista de José I. Hay consenso en aceptar la cifra de unos 12.000 afrancesados, pues aproximadamente ésos fueron los

94. No obstante, hubo disensiones entre los afrancesados que ocupaban altos cargos y el generalato francés, como puede verse en ScOTTI, Vittorio. "La justicia y la Gracia: desavenencias y riñas entre militares franceses y autoridades josefinas». En BuTrón PRIDA, Gonzalo y RAmos SANTANA, Alberto (eds.). Intervención extranjera y crisis del Antiguo Régimen en España. Huelva: Universidad de Huelva, 2000, pp. 131-147.

95. Un profundo estudio es el de Moreno Alonso, Manuel. El clero afrancesado en España. Los obispos, curas y frailes de José Bonaparte. Madrid: Biblioteca Nueva, 2014.

96. Una obra no sólo esencial para entender el afrancesamiento, sino pródiga a la hora de proponer líneas de investigación, es la de LóPEz TABAR, Juan. Los famosos traidores. Los afrancesados durante la crisis del Antiguo Régimen (1808-1833). Madrid: Biblioteca Nueva, 2001.

97. Los afrancesados ha sido reeditado en varias ocasiones. La última fue por Alianza Editorial en 2008 
que, con sus familias, se exiliaron a Francia a partir del otoño de 1812, con la progresiva retirada del ejército napoleónico de España culminada en 1813. En esencia, el afrancesamiento tuvo su epicentro en Madrid, en la corte, donde se controlaban los resortes del poder.

Los juramentados o colaboracionistas (afrancesados pasivos) fueron los hombres que, por necesidad, para no perder sus puestos de trabajo o sus rentas y ante el temor a ser represaliados, juraron fidelidad al rey y continuaron trabajando en la administración y en la posesión de sus tierras. Fueron decenas de miles, y sostuvieron el aparato burocrático en los pueblos y ciudades. Según Artola, «son los más y menos interesantes desde el punto de vista político por cuanto no tienen ninguna representación ${ }^{98}$. No le falta razón. Es cierto que todos ellos sufrieron presiones, se vieron coaccionados a jurar fidelidad al Rey Intruso, pero se hace preciso investigar las razones de su adscripción y hasta qué punto su labor fue importante en el sostenimiento del régimen.

En un interesante artículo Claude Morange ha propuesto emplear el vocablo josefinos en vez de afrancesados ${ }^{99}$, al considerar que el término está despojado de carga semántica negativa y es una aséptica definición. Pero nosotros utilizaremos ambas voces como sinónimas, pues pensamos que lo que movió a los afrancesados a apoyar a José I (por lo menos en el comienzo de su reinado) no fueron sus aptitudes como gobernante filósofo ${ }^{100}$, sino las de su hermano Napoleón. Es un hecho que el primogénito de los Bonaparte tenía buenas condiciones personales (había estudiado Leyes, era instruido, dialogante, pragmático, hacía gala de bonhomía) ${ }^{101}$, aptitudes resaltadas por la literatura propagandística (siempre, eso sí, proclive al ditirambo) y por sus dos años de reinado napolitano ${ }^{102}$, pero a los afrancesados lo que les deslumbraba era el bonapartismo: un régimen moderno capaz de conciliar con eficiencia orden y progreso, promotor de la valía personal con independencia del origen familiar, valedor de las libertades civiles, defensor

98. ARTOLA, Miguel. La España de Fernando VII. Madrid: Espasa, 1999, pp. 236-237.

99. Morange, Claude. "¿Afrancesados o josefinos?". Spagna contemporanea, 2005, 87, pp. 27-54.

100. José I se tenía a sí mismo como un rey filósofo, como desarrolla Dufour, G. «Le Roi philosophe». Mélanges de la Casa de Velázquez, 2008, 38 (1), pp. 53-70. Asimismo, Diego García, Emilio de. «El reinado imposible del rey filósofo». Cuadernos de Investigación Histórica, 26, 2009, pp. 141-157.

101. Para los aspectos biográficos, es fundamental la obra de Moreno Alonso, M. José Bonaparte. Un rey republicano en el trono de España. Madrid: La Esfera de los Libros, 2008. También, para entender cómo era visto José Bonaparte en las dos Españas enfrentadas, véase PIQueres, A. "José I, maléfico o divino». En LA PARRA LóPEZ, E. (coord.). La imagen del poder. Reyes y regentes en la España del siglo XIX. Madrid: Síntesis, 2011, pp. 77-132.

102. Estas buenas condiciones de gobernante sobresalen aún más si las comparamos con las de su rival Fernando VII, que a pesar de algún intento revisionista historiográfico de ponderar sus dotes gubernativas y su inteligencia, fue diseccionado por la pluma de Napoleón durante su aislamiento y estadía francesa en jaula de oro en estos términos: "No muestra interés por nada, es sumamente materialista, come cuatro veces al día y no tiene juicio formado sobre ninguna cosa", según extracto de la correspondencia del emperador recogida por ChANDler, David. Las campañas de Napoleón. Madrid: La Esfera de los Libros, 2005, p. 648. 
de la propiedad y debelador de los derechos feudales. El Sistema Continental -con la forzada satelización de países en torno al astro francés- que el genio militar de Napoleón construía en Europa merced a las bayonetas era, desde la óptica afrancesada, una oportunidad de oro para que España se incorporase a ese sistema imperial en situación ventajosa. Por eso, no es descabellado imaginar que, si otros hermanos del emperador no hubiesen rechazado la Corona, los afrancesados españoles -al menos al principio- hubiesen tributado a ese hermano la misma adhesión que a José, ya que en puridad, ante todo, eran bonapartistas. O mutaron en tales con celeridad, tras las vergonzosas abdicaciones de Bayona y el hecho consumado de estar el ejército francés disperso por amplias zonas del país. Sin embargo, sí podemos distinguir entre colaboracionistas renuentes (la mayoría) y colaboracionistas interesados.

Públicamente, los juramentados o colaboracionistas renuentes se cuidaban de expresar sus verdaderas opiniones políticas o sus sentimientos hacia la causa patriótica. Se limitaban a aceptar con resignación el estado de cosas. Negarse a prestar juramento de fidelidad a José I implicaba la pérdida automática del empleo y malquistarse con los ocupantes. ¿Y qué otra opción tenían? Sólo una, y dramática: renunciar a su trabajo y posesiones, abandonar su hogar, buscar refugio en zona patriota (al final, sólo Cádiz), vivir precariamente y cargar con la familia teniendo un horizonte vital lleno de incertidumbre. Eso explica que muy pocos optaran por esta vía. Una de las excepciones que merece comentarse fue la del portero de la casa consistorial de Linares (Jaén), que no quiso jurar, perdió su modesto puesto laboral y para no ser represaliado, se escondió en su propio pueblo. Terminada la guerra, los juramentados coincidirán en alegar que sus motivaciones fueron, ante el vacío de poder sobrevenido, evitar dejar desprotegidos a sus convecinos, algo que hubiese sucedido si la administración se hubiese colapsado ${ }^{103}$.

También hubo juramentadas: las viudas de empleados públicos que recibían una paga. Incluso hubo puntuales casos de mujeres que se enrocaron en una resistencia pasiva al negarse categóricamente a prestar el juramento de lealtad al rey, como fue el caso de la Junta de Damas de la Económica de Amigos del País matritense, arguyendo triquiñuelas jurídicas, hasta que en el verano de 1809, ante el incremento de las presiones de la administración, las viudas se vieron obligadas a prestarlo para no caer en la indigencia.

Los patriotas denigraron a las esposas de los afrancesados exiliados y las atacaron con saña en sus escritos tachándolas de «víboras emponzoñadoras», de "traidoras» y de haber gozado de «banquetes opíparos» y "orgías crapulosas»104. La batería de insultos misóginos contra las madamas fue una constante entre los

103. Un agudo análisis es el de Moreno Alonso, Manuel. Los españoles durante la ocupación napoleónica. La vida cotidiana en la vorágine. Málaga: Algazara, 1997, pp. 71-90.

104. Así escribió sobre las mujeres de los afrancesados el fraile Manuel Martínez en el periódico El Conciso, 9 de septiembre de 1813, núm. 9, p. 7. 
escritores patriotas, a las que califican de "malas hembras", dadas a "comilonas y borracheras" con los francmasones, que "cantan con insultos contra la patria", "sanguijuelas que chuparon abundantemente la sangre del buen español» ${ }^{105}$.

Hubo mujeres colaboracionistas por razones sentimentales, pues en un contexto de guerra, viudas, con sus maridos o novios presos, muertos o combatiendo fuera de sus casas enrolados en el ejército o la guerrilla, se relacionaron con soldados franceses de diversas maneras: al alojarlos en sus hogares, tratarlos en tertulias y cafés, trabajar para ellos como sirvientas, ejercer de enfermeras en hospitales, trabajando como vendedoras ambulantes y suministrando mercancía a las tropas invasoras, e incluso como espías o prostitutas que obtuvieron información para los franceses.

También habrá casos de mujeres que mantengan relaciones consentidas con soldados de la Grande Armée, en un ejemplo de lo que en la Segunda Guerra Mundial se denominará eufemísticamente colaboración horizontal. Podemos citar el caso de Málaga, pues en febrero de 1810 se instaló en la ciudad una división polaca integrada en el ejército de Sebastiani. Los oficiales polacos, rubios y de ojos claros, se fijaron en las mujeres, de las que les agradó su belleza, su gracia y su falta de timidez, por lo que estos militares de graduación causaron furor entre las malagueñas, las cuales serían amonestadas y castigadas con posterioridad ${ }^{106}$. Pero los castigos ejemplarizantes también serán administrados por colaboracionistas contra mujeres patriotas, como fue el caso de la ciudad de Ronda, en la que varios policías, al registrar a María la Tinajera para buscar cartas y papeles destinados a patriotas, la sometieron a ultrajes, la desnudaron, la encarcelaron en unión de otras quince mujeres acusadas de espionaje, la sacaron de la celda, la raparon con una escoda de soldado e incluso quisieron emplumarla como a una prostituta o una adúltera. A continuación, los policías la pasearon por la ciudad acompañados por varios afrancesados (destacó José Llanes de Vargas) que incitaban a sus conciudadanos a insultar "a la rapada» ${ }^{107}$. Por último, bajo el sonido de cajas destempladas (tambores destensados), la expulsaron de la ciudad entre insultos conminándola a no volver so pena de ser fusilada.

Un grupo profesional en el que deslindar las fronteras del afrancesamiento y colaboracionismo resulta muy complicado es el de los científicos o, como propone José Ramón Bertomeu, cultivadores de la ciencia, pues la edad, el cargo ocupado y el lugar de residencia motivaron su adscripción a un bando u otro ${ }^{108}$. Todos ellos,

105. La Atalaya de la Mancha, 15 de marzo de 1814. Un buen estudio de las mujeres que simpatizaron por diferentes razones con la causa bonapartista, es el de MARTíN-VALDEPEÑAS YAGÜE, Elisa. "Mis señoras traidoras: las afrancesadas, una historia olvidada». Revista HMiC, 2010, 8, pp. 79-108. 106. REDER GADOw, Marion. "Vida cotidiana en Ronda durante la Guerra de la Independencia”. Baetica. Estudios de Arte, Geografía e Historia, 2007, 29, p. 388.

107. REDER GADOW, Marion. "La vida...", op. cit., pp. 404-405.

108. BerTomeu SÁnchez, José Ramón. "La colaboración de los cultivadores de la ciencia españoles en el gobierno de José (1808-1813)». En Gil Novales, Alberto (ed.). Ciencia e independencia 
al estudiar y desarrollar su actividad científica (algunos fueron pensionados para estudiar en el extranjero o viajaron al formar parte de comisiones científicas) estuvieron en la órbita de la Ilustración, por lo que el racionalismo era su sistema de pensamiento. Pero en el momento crucial de 1808, la toma de decisiones (donde el sistema de valores y las emociones tienen un peso análogo a la estructura mental racional) hizo que la mayoría -si nos ceñimos al grupo de científicos más destacados en ese momento- optase por el bando patriota (147 hombres de ciencia), frente a una minoría que lo hizo por el partido josefino (79 personas). Los de más edad se inclinaron por los Bonaparte, pues el $77 \%$ de quienes se afrancesaron vivían en Madrid (foco del poder) o en ciudades importantes, y al ocupar puestos en universidades e instituciones temían perder sus cargos y honorarios; mientras que los más jóvenes aún no habían consolidado su carrera académica (o se hallaban en las aulas universitarias), no fueron obligados a prestar juramento de fidelidad al rey y por consiguiente tuvieron más libertad para enrolarse en los ejércitos patriotas en calidad de ayudantes médicos, cirujanos, farmacéuticos, veterinarios, militares con formación matemática, náutica o de ingeniería. Estos científicos jóvenes estaban dispersos por el país y fueron huyendo de las tropas francesas hasta terminar recalando en Cádiz.

Sin embargo, aunque constituyeron una ínfima minoría, también habrá fervorosos afrancesados en el ámbito provincial y local, distinguiéndose de los meros colaboradores.

En Santander tenemos ejemplos de familias afrancesadas, como los Peredo, cuyos miembros se adhirieron con entusiasmo al partido josefino, destacando Antonio Peredo Boo, nombrado secretario del comisario regio Francisco Amorós. Las familias cántabras Aldamar y Cebelio se identificarían también con los bonapartistas, y algunos de sus miembros recibirían importantes cargos en la administración. Los lazos familiares anudaban ventajosos negocios, aseguraban importantes puestos de trabajo y propagaban en la ciudad noticias favorables al régimen. Antonio de Ojesto fue administrador general de rentas y comandante en jefe del batallón de la Guardia Nacional santanderina, el cuerpo militar josefino en el que se alistaron varios cientos de colaboracionistas ${ }^{109}$.

También habrá un colaboracionismo interesado motivado por motivos económicos, personales o políticos. Eran arribistas, oportunistas. Se arrimaron a los ocupantes (y virtuales vencedores en la contienda) buscando el medro, el ascenso profesional. Este tipo de colaboracionistas, tan recurrente en todas las guerras y bruscos cambios de régimen, será difícil de detectar en el cribado histórico, aunque podemos identificarlos por ser quienes se exiliaron a Francia y generaron

política. Madrid: Ediciones del Orto, 1996, pp. 175-213. Asimismo, del mismo autor, La actividad científica en España bajo el reinado de José I (1808-1813). Un estudio de las instituciones. Valencia: Universidad de Valencia, 1995.

109. GuERrero EleCAlDE, Rafael. "Colaborar con...», op. cit., pp. 167-219. 
entre sus convecinos el convencimiento de haber amasado un capital mediante el expolio o la coacción, o bien desempeñaron tareas policiales, represivas.

Un palmario ejemplo de colaboracionismo interesado es el de las brigadas de Guardacostas Nacionales que en mayo de 1809 reforzaban el nudo estratégico guipuzcoano de Guetaria. Sus setecientos hombres habían salido de las cárceles: eran convictos juramentados, presos excarcelados tras haber prestado juramento de lealtad a José $\mathrm{I}^{110}$. Los altos funcionarios josefinos eran conscientes de la catadura de esos hombres y de su maleabilidad política, pero pensaban que merecía la pena correr el riesgo, pues lo importante era sumar esfuerzos para combatir a los patriotas y asentar la Corona bonapartista. Aunque se tratase de delincuentes.

Otras ciudades también contaron con conocidos malhechores reconvertidos en agentes del orden josefinos, caso de la localidad sevillana de Lebrija, donde el conocido como Pantalones se incorporó en el cuerpo de policía bonapartista para ganarse la confianza de patriotas y luego detenerlos con pruebas ${ }^{111}$. En Linares, un minero, Fernando Pajares, y su familia huyeron a Francia con las tropas imperiales y él no regresó. Algo que sí hicieron en 1813 sus dos hijas, que, en una delicada situación económica, abrieron un colegio en la calle de los Álamos, pero como sus convecinos las estigmatizaron socialmente, la escuela fracasó y se vieron obligadas a exiliarse de nuevo.

El comisario de policía de Córdoba, Esteban Díaz Guijarro, acumuló tal animadversión que acompañó a los imperiales en la retirada del verano de 1812 y se exilió en la ciudad de Lectoure. En una inusitada torsión ideológica, este antiguo colaboracionista se hizo carlista (no se atrevió a regresar a Córdoba), participó en la expedición del general Gómez y murió en los pinares de Soria ${ }^{112}$.

El arquetipo de colaboracionista interesado fue el abogado barcelonés Ramón Casanova. En 1808 trabajaba como agente de negocios, tenía gran cantidad de deudas (por su tren de vida) y manifestaba continuos deseos de ascenso social. No se le conocía afrancesamiento cultural, tan sólo un fuerte sentimiento anticlerical. Al ocupar Barcelona el ejército francés se ofreció como colaborador, y el 30 de julio de 1808 fue nombrado comisario general de Policía de Barcelona. Casanova eligió a sus subordinados (casi cuarenta hombres), actuó bajo la dirección de los militares franceses y su celo permitió desarticular dos conspiraciones. Aprovechó su cargo para extorsionar a bastantes barceloneses detenidos por conducta política sospechosa, prometiéndoles acelerar los trámites de su puesta en libertad; autorizaba el registro de viviendas de familias pudientes para confiscarles joyas; aceptaba sobornos de comerciantes para sacar de la ciudad mercancías prohibidas

110. FERNÁNDEZ SiRVENT, Rafael. "Un comisario regio de José I: Francisco Amorós». Historia Constitucional (revista electrónica), 2008, 9, pp. 95-96, http://hc.rediris.es/09/index.html.

111. Álvarez-Benavides, Alfonso. Curiosidades sevillanas (edición facsímil). Sevilla: Universidad de Sevilla, 2005, p. 291.

112. VENTURA Rojas, José Manuel. La provincia de Córdoba de la Guerra de la Independencia al reinado de Isabel II (1808-1833). Tesis doctoral. Córdoba: Universidad de Córdoba, 2007, p. 672. 
y extorsionaba a grupos de negociantes navieros ${ }^{113}$. Su arbitrariedad en el denominado caso Cantón (que supuso el fusilamiento de José Cantón, un rico usurero de origen milanés) motivó que en 1810 los franceses lo destituyeran al frente de la policía, lo paseasen maniatado por las calles barcelonesas y condujesen a Paris para encarcelarlo, terminando allí sus días «uno de los individuos más repugnantes que militaron en el partido afrancesado" ${ }^{114}$.

Asimismo hubo pequeñas corruptelas que beneficiaron a colaboracionistas, repartiendo entre ellos algunos bienes procedentes de monasterios suprimidos. Es el caso de Pamplona, donde Pío Jaén recibió una alfombra procedente del convento de la Merced; Andrés Carrascón una efigie del Cristo de los Milagros y otra de la beata María Ana de Jesús, pertenecientes al mismo cenobio que la talla del Cristo ${ }^{115}$.

En conclusión, el colaboracionismo renuente fue el denominador común en la administración provincial y local, mientras que el afrancesamiento fue un fenómeno casi exclusivamente cortesano. En el paréntesis del régimen constitucional (verano de 1812-1814) y en los inicios del Sexenio Absolutista, los juramentados se las arreglarán para salir básicamente indemnes de los numerosos procesos de depuración política incoados a nivel local ${ }^{116}$, y conforme los afrancesados vuelvan del exilio a lo largo del reinado de Fernando VII, ocuparán los puestos intermedios de la administración, y, reconvertidos en tecnócratas ${ }^{117}$, pondrán en marcha lo que podríamos denominar una transición silenciosa que, aun de proyección política modesta, ayudará a cambiar la fontanería del Antiguo Régimen para cuando llegue la hora de los liberales en 1833. Será la postrera victoria de los antiguos afrancesados, que se integrarán sin chirridos en el liberalismo moderado.

113. Riera Fortiana, Enric. "Algunos casos de afrancesamiento entre los hombres de toga barceloneses durante la Guerra de la Independencia». Pedralbes: revista d'història moderna, 1984, 4, pp. 273-324.

114. MERCADER RIBA, Juan. Barcelona durante la ocupación francesa. 1809-1814. Madrid: CSIC, 1942, p. 102.

115. Andueza UnANuA, Pilar. "Una aproximación al impacto de la Guerra de la Independencia, la desamortización josefina y la legislación de las Cortes de Cádiz sobre el patrimonio cultural de Navarra». Príncipe de Viana, 2012, 256, p. 727.

116. LARA López, Emilio Luis. "La represión de los afrancesados: condenas sociales, jurídicas y políticas. El caso de Jaén (1812-1820)». Hispania Nova, 3, 2003, http://hispanianova.rediris.es/articulos/03_001.htm.

117. López Tabar, Juan. Los famosos..., op. cit., pp. 271-354. Moral Roncal, Antonio Manuel. ¡El enemigo en Palacio! Afrancesados, liberales y carlistas en la Real Casa y Patrimonio (1814-1843). Alcalá de Henares: Universidad de Alcalá, 2005. 